\title{
COMMERCIAL
}
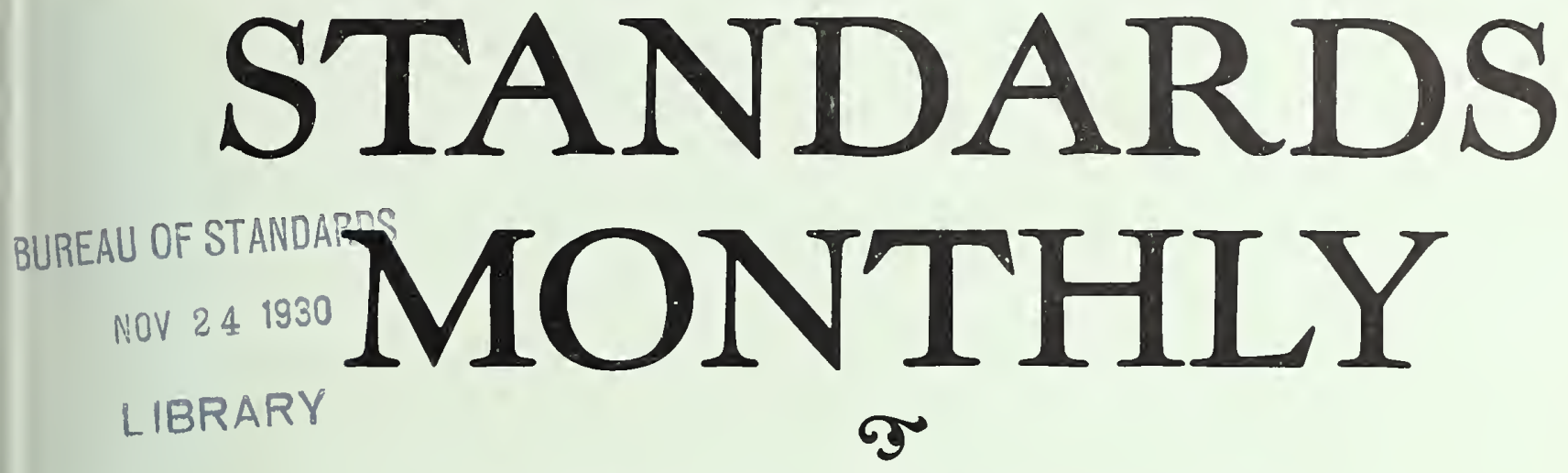

\section{A Review of Progress in}

\section{Commercial Standardization and Simplification}

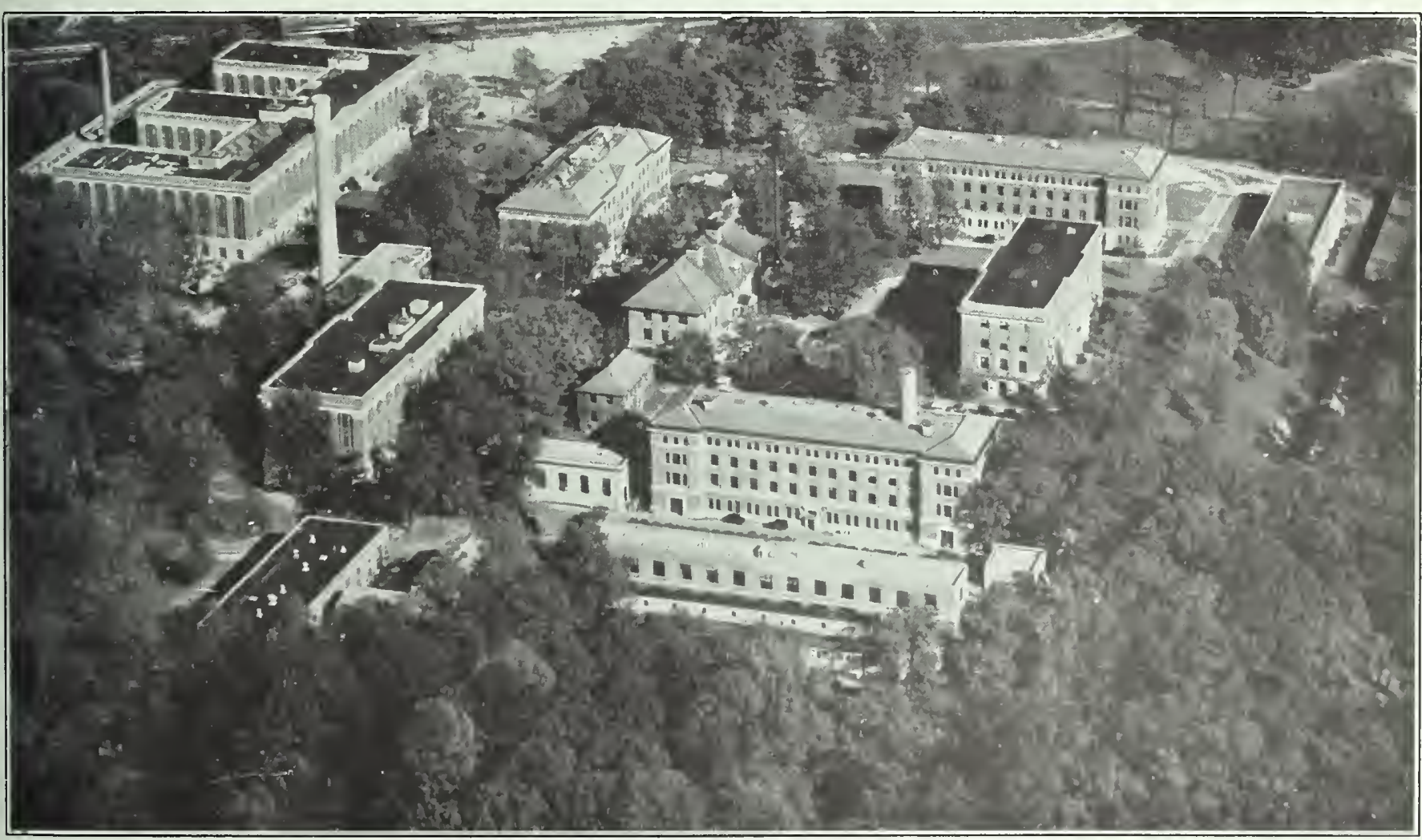

AIRPLANE VIEW OF NATIONAL BUREAU OF STANDARDS

ISSUED BY THE NATIONAL BUREAU OF STANDARDS OF THE UNITED STATES DEPARTMENT OF COMMERCE, WASHINGTON, D.C., U.S.A.

Vol. 7, No. 5

NOVEMBER, 1930 


\section{U. S. DEPARTMENT OF COMMERCE \\ R. P. Lamont, Secretary \\ NATIONAL BUREAU OF STANDARDS \\ George K. Burgess, Director}

COMMERCIAL STANDARDS MONTHLY

S. F. TILLMaN, Editor

\section{DIVISIONS OF THE COMMERCIAL STANDARDIZATION GROUP}

DIVISION OF SIMPLIFIED PRACTICE, EDWIN W. ELY.

The division of simplified practice was formed in November, 1921 , to provide a clearing house or centralizing agency through which the manufacturer, distributor, and consumer groups cculd meet to diseuss their common problems and decide upon eliminations which would prove of mutual benefit to all con. cerned. The activities of the division are purely cooperative in character. It orders nothing; it dictates nothing; the initiative must come from business itself. It has no regulatory nor police powers to enforce adherence to the simplified-practice recommendations that industry develops under the auspices of the United States Department of Commerce. Its chief function is to selve as a neutral meeting ground for the purpose of bringing together producers, distributors, and consumers, whose aims are sometimes divergent and possibly antagonistic, and who would be unwilling to cooperate, except through some unbiased central agency. Following the approval of the tentative simplified-practice recommendation by a general conference of all interested elements thereof, the project is then presented to the entire industry by letter referendum for its approval and written acceptance, the publication and indorsement of the recommendation on the part of the Department of Commerce being dependent upon acceptance of the program by at least 80 per cent, by volume, of the manufacturers, distributors, and users concerned.

\section{BUILDING AND HOUSING DIVISION, J. S. TAYLOR.}

The division of building and housing cooperates with business, technical, and professional groups in practically all its undertakings on building and housing. Its work to modernize building codes and to encourage improved standards for the quality of building construction promotes the practical application of the latest development in design and use of building materials. This division was also formed in 1921.

In furthering home ownership, an effort is made to develop an enlarged, steadier, more intelligent, and more discriminating demand for soundly built dwellings, the largest single class of buildings which the construction industries provide. The division also cooperates with many business and professional groups in efforts to distribute $l$ uilding activity more evenly throughout the year, and to secure less fluctuation from year to year. The work on city planning and zoning lias in mind the broad objective of buildings made more useful because well located with respect to other buildings, a well-coordinated street system, and appropriate public works. Good city planning and zoning likewise encourages stability in land values and property uses, and thereby contributes to the demand for durable structures.
DIVISION OF SPECIFICATIONS, A. S. MCAllister.

The duties of the division of specifications are to promote and facilitate the use and unification of specifications. In doing so it carries on activities involving cooperation with technical societies; trade associations; Federal, State, and municipal Government specifications making and using agencies; producers, distributors, and consumers; and testing and research laboratories. The cooperation with technical societies and trade associations includes ascertaining the standardization and specification promoting activities of these organizations, and bringing to their attention the work being done by the commercial standardization group. The cooperation with governmental agencies and other consumers includes the bringing of Federal specifications and commercial standards to the attention of the maximum number of producers and the maximum number of users of commodities complying with these specifications and standards, thereby assisting in broadening the field of supply. The cooperation with producers involves the compilation and distribution of lists of manufacturers who have expressed their willingness to certify to purchasers, upon request, that material supplied by them on contracts based on certain Federal specifications or commercial standards comply with the requirements thereof. The cooperation with distributors involves bringing to their attention the benefits to be derived by them as both buyers and sellers from handling nationally specified, certified, and labeled commodities. The division prepares the directories of governmental and nongovernmental testing laboratories; the Directory of Specifications; and is working on an encyclopedia of specifications, the first volume of which, Standards and Specifications in the WoodUsing Industries, has been issued. It also aids in preparing the Standards Yearbook.

\section{DIVISION OF TRADE STANDARDS, I. J. FAIRCHILD.}

The commercial standards unit, now known as division of trade standards, was created on October 1, 1927, for the purpose of aiding those industrial and commercial groups desiring to establish standards of grades, quality, or measurements for their products or their purchases on a purely voluntary basis.

The division functions only at the direct request of the industry concerned. Its procedure is similar to that of the division of simplified practice, except that at least 65 per cent of the industry, by volume of annual production, must accept the commercial standard in writing before it is published by the Department of Commerce. A certification plan is applied on request as a means of increasing the effectiveness of such standards. Provision is made for regular revision of the standard through the appointment of a standing committee to consider periodically any necessity for revision of the standard, in order that it may be kept constantly compatible with progress in the industry.

Except where otherwise indicated, for further information address 


\section{COMMERCIAL STANDARDS MONTHLY \\ A Review of Progress in \\ Commercial Standardization and Simplification}

Volvme $T$

WASHINGTON. D. C., NOVEMBER, 1930

Nudiber 5

\section{CONTENTS}

\section{FEATURE ARTICLES}

Aid in identifying quality in household commodities Benefits from simplifying varieties in sof twood lumber

Bituminous materials tested

Development of Navy specifications

Home-ownership drive

Industrial progress through research and standardization

Simplified practice-a clearing house

Standard railway track scales for light ind ustrial service

Standards in the manufacture of fish meal .........

Tile industry reduces cost of manufacture through standardization

The Government laboratory and industry ..........

The "Reichskuratorium fuer Wirtschaftlichkeit" (R K W).

\section{TRADE STANDARD NEWS}

Excellent adherence noted to standard on regain of mercerized cotton yarns.

Manufacture of wall paper 70 per cent on standard specification

Pamphlet on American national standard screw threads available

Standardization of mop sticks

Standard for interchangeable ground-glass joints released

Success of mirror standard assured.

Vitreous china plumbing fixture standard

\section{FOREIGN NEWS}

Architects in Finland studying standardization of plywood doors .

Italian standardizing society formed

Standardization of lubricating oils and greases in Belgium -

Page
131
148
151
133
149

130
134
137
144
140
153
155

156

158

159

159

133

159

159

158

136

132

SPECIFICATION NEWS
Certification plan to be applied to bricks
Certifying hardwood and softwood lumber.
Indorsement of quality labels by American Home Eco-
nomies Association.

\section{SIMPLIFIED PRACTICE NEWS}

Ninety-six stock sizes of Turkish towels will be reduced to six

Recent economic effects of simplified practice

To reduce waste in distribution of merchandise.

Current activities of American Marine Standards Com mittee

\section{STANDARDIZATION NEWS}

Current activities of the American Standards Associaederal specifications printed in standard form

Frogs used to test standard drug potency

Increase noted in testing work.

Interlingual public address system

McAllister, new Assistant Director of Bureau of Standards

New circular on cleaning materials

New design of precision resistance standard

New and revised publications issued by the Bureau of Standards

Official time-zone map of the United States, issuerl by Bureau of Standards

Standard fire-fighting equipment for metal mines approved .......

Standardization briefs

Standardization of printing and writing papers

Standardizing lithographic papers.

Status of Federal specifications

Tentative specification developed for stainless lubricant.
Page

\section{AN INVITATION TO VISIT THE BUREAU OF STANDARDS}

An interesting fact in the growth of the bureau is the steady increase in the number of visitors. From all over the world experts come to see the work in progress in many specialties. Not alone the experts but in growing numbers many of our people visit the bureau from a public-spirited desire to acquaint themselves with its research w ork. All visitors-from the newspapermen, who have called the bureau a "house of wonders," to the specialists, who use its services-are welcome, for it is their bureau in a very real sense. They are the owners of the business and its beneficiaries. The annual per capita cost of 2 cents which the average citizen pays toward the operation of the bureau yields returns sometimes a hundredfold or a thousandfold. How science turns wastes into profits, increases the useful life of materials, adds new efficiencies to industry, advances new arts, such as aviation and radio, by research and discovery-these are to be seen first-hand in the scientific and technical laboratories of the bureau.

A cordial invitation is extended to all citizens interested in scientific progress to visit the laboratories of the Bureau of Standards when in Washington. A personally conducted trip is organized at $2.15 \mathrm{p} . \mathrm{m}$. daily except on holidays. Special trips for groups may be arranged at other times by writing to the bureau in advance. 'The bureau's illustrated Visitor's Manual may be had for the asking. This lists the work in progress and gives an airplane view of the ensemble and a brief statement of typical discoreries and inventions which have been notable, basic contributions to radio, aviation, and other modern arts and industries.

George K. Bungess, Director. 


\title{
INDUSTRIAL PROGRESS
}

\author{
Through RESEARCH and \\ $S T A \mathcal{N} D A R D I Z A T I O N$
}

$W_{\text {HEN }}$ the measurements which insure high quality are found by research, the data become working factors in industry quite as definite as its tools and machines. Such data translated into measured controls are known as "standards."

Standards govern industry. They are fiducial points of human achievement, pointing the way to further progress. A standard is a congeries of measurements - at once an attainment and a challenge.

A success once attained experimentally may thus be put to mass production with uniformly high quality assured. The best magnitudes may never occur in service. If they did so occur, they might not be recognized as the best.

The optimum magnitudes of dimension or properties are produced and observed as a matter of course, in experimental research where conditions varied singly, step by step, give a full survey of the effect of each variation, as a basis for the design of apparatus or new specifications for materials or processes.

Vast volumes of numerical data concerning nature, its materials, forces, phenomena - data from research - are all potential servants of industry. They, too, are bases for design.

With measured production runs parallel the standard test: Limit gages insure dimensional accuracy; tests maintain standard quality. Concurrently service research correlates the measured description, the standard, with the performance it is designed to insure.

Permissible variations, fixed in units of measure, allow for assembling, fitting, interfunctioning of parts, and for economy of production where extreme accuracy is costly.

In research to fix production standards, the technique and equipment in the laboratory become tools of industry - the induction furnace, the photo-electric cell, the quartz oscillator-once factors in experiment have become factors in production.

The analysis of a process may be so complete that each item may be made automatic, both in detail and ensemble. Staffs shift from production to planning or to new types of service which call for research.

To apply science to industry we learn to use standards, periodically stepped up to higher levels, while research touches with creative power every aspect of production which becomes steadily more automatic. Provision for human needs and desires thus grows easier, cheaper, and more complete, while life is enriched at an ever accelerating rate. 


\title{
AID IN IDENTIFYING QUALITY IN HOUSEHOLD COMMODITIES
}

\author{
Outlines of Plans for Aiding Consumers in Obtaining Qualities Called for by Nationally Recognized \\ Commodity Specifications
}

\author{
By A. S. McAllister, National Bureau of Standards
}

At an ever-increasing rate the National Bureau of Standards is receiving requests for information concerning the relative merits of various trade-branded goods tested by the bureau. These requests emanate from the officers and members of such organizations as the American Home Economics Association, the General Federation of Women's Clubs, and many dealer and consumer groups.

To the numerous requests for data concerning tradebranded goods, the publication of which would be welcomed by many and opposed initially by few, serious consideration has been given. The conclusion has been that the best method for passing along to the public the benefit of the tests and investigations made at the National Bureau of Standards is to place the results of the research at the disposal of committees formulating nationally recognized specifications (which may or may not be those of the Federal Government), and to bring into cooperative relations the firms desiring to manufacture goods to comply with these specifications and the purchasers who wish to buy specification-made goods.

A suitable solution to the present-day marketing problem would seem to be to induce the producers, distributors, and consumers to think in terms of specifications. So far as concerns the producers and such consumers as buy directly from manufacturers on definite contracts, there are reasons for believing that a satisfactory solution has been found in the so-called "certification plan." The real problem is to expedite the application of this plan to the maximum number of specifications for commodities in which the consumer's are interested.

The "certification plan" involves the compilation and distribution of lists of manufacturers desirous of obtaining contracts based upon certain selected nationally recognized specifications, and willing, when requested to do so, to certify to the purchaser that the comnodities delivered are guaranteed to comply with the requirements and tests of the specifications.

There are several reasons for developing the certification plan, namely: (1) To make thoroughly effective the benefits to be derived by producers and consumers from the well-known economies incident to mass production, mass distribution, and mass consumption; (2) to encourage the producers to manufacture staple commodities to comply with nationally recognized commodity specifications; (3) to assist the producers in expanding their markets for staple commodities complying with nationally recognized specifications; (4) to facilitate and expand the use of nationally recorgnized commodity specifications by large-quantity and medium-quantity buyers; (5) to determine the commercial acceptability of certain nationally recognized specifications; $(6)$ to aid in unifying the specifications rsed throughout the country; and (7) to broaden the source of supply of products conforming to nationally recognized specifications.

\section{Quality in household commodities.}

Many of the specifications to which the certification plan has been or will be applied, cover commodities of much interest to housekeepers. Although it is not expected that the housekeeper will actually buy commodities on individual specifications, some day she may be induced to confine her purchases of certain kinds of commodities to those known to be manufactured to comply with certain nationally recognized specifications. Perhaps she may even now be induced to examine critically such of these commodities as she does purchase to determine whether or not they are as represented and will comply with her own requirements-to purchase on the basis of real quality and ability to meet service requirements rather than on the basis of superficial appearance or of the numerous kinds of sales arguments.

No serious difliculty would be encountered in compiling material for a publication or series of publications deroted to "specifications for household commodities." In fact. considerable material of this nature is now available.

Most of the existing household commodity specifications have been written in technical language and probably could not be directly utilized by the housekeeper. In certain cases the specifications could be written in easily understandable language, but it is not self-evident that they would be made use of, as specifications, even in the simplified form.

A study of the present marketing situation has indicated that housekeepers would welcome the preparation for their use of a series of "hand-bag size" pamphlets or folders outlining methods of identifying quality in certain kinds of commodities and giving very simple rough-and-ready tests which could be applied by them in the homes or stores.

Moreover, inquiry has developed the fact that organizations that can properly be assumed to be interested more or less in the informative household commodity pamphlets are desirous of having such pamphlets prepared for wide distribution and can be counted upon to cooperate in the selection of the commodities and in the preparation of the material to be included in the pamphlets.

Probably only fairly rapid progress can be made in the preparation of the pamphlets referred to. In any event, it appears desirable to expedite the application of the "certification plan" to specifications for household commodities and to supplement this plan by a labeling plan to bring to the "over-the-counter" buyers many of the benefits derived by the large-quantity contract purchasers from the use of the certification plan.

\section{Labeling plan.}

In accordance with the self-identifying, qualityguaranteeing labeling plan, a firm desirous of bringing effectively commodities guaranteed to comply with the 
requirements of certain nationally recognized specificcations to the attention of the "over-the-counter" buyer at the time of making a purchase, places on the individual commodities or their containers labels which definitely identify both the specification and manufacturer or the trade association which holds itself responsible for the guaranty.

The labeling plan, in one form or another, has been in operation for many years, and identifying labels (some carrying guaranties) are being advocated by about 100 national technical societies and trade associations, many of whom maintain inspectors for making their labels effective.

Before discussing with individual manufacturing firms the use of self-identifying, quality-guaranteeing labels, it was thought desirable to bring the labeling plan to the attention of the officers of every technicai society and trade association on the bureau's mailing list. Much interest has been manifested by these officers. Even those agencies which might be expected to be opposed to such an activity have not been unmindful of the considerable agitation during the past year or so in faror of making it possible for the pullic to buy merchandise on a pure quality basis without regard to the merits claimed by its producers.

It is believed that a great improvement orer the conditions under which the purchaser is at the mercy of the seller is represented by the plan in accordance with which manufacturers definitely identify such commodities as they are willing to guarantee to be made in accordance with nationally recognized specifications-a majority of which are not those of the Federal Government.

There may be some doubt as to whether or not the specification method of buying and the marketing of specification-made goods for purchase by the nonspecification nser are now being forced by the consumers upon unwilling manufacturers. However, it seems evident that quality-basis marketine methods are making considerable headway. This fact is to be attributed quite largely to the increasing recognition of the adrantages in the specification method of buying and to the realization of the existence of excessive economic waste in the older marketing methods.

From the point of view of the manufacturer, the dealer is a consumer: as seen by the consumer, the dealer is the equivalent of a prodicer. It would seem. therefore, that the dealer is in excellent position to form worth-while opinions concerning modern trends in merchandising. Numerous wholesale and retail organizations, several of them national in scope, have expressed their interest in both the certification and the labeling plans and see in these plans the foundation for a solution to some of their important merchandising problems.

By labeling, advertising, and guaranteeing certain commodities to meet the requirements of nationally recognized specifications, manufacturers will be able to meet the "newer competition." The division of business between competing firms will be determined, not by the price alone but by price combined with reputation for fair dealing-good will, if you please. Good will is an asset which should continue to bring in profits under competitive, quality-basis merchandising.

It will be observed that both the certification and labeling plans are dependent upon the preparation and promulgation of adequate specifications. The need at the present time is for specifications-more specifications-and better specifications. Some of these specifications can be written in language readily understood by the purchasers, whereas others must be presented in terms which can be understood only by technical experts. It is desirable but not essential for specifications to be expressed in language usually understood by persons of ayerage intelligence and education.

The essential requirements are that purchasers, distributors. and consumers agree on the specification requirements; that manufacturers know how to produce materials to comply with these specifications; and that testing laboratories know how to determine whether or not commodities comply with the specification requirements. If. then. the public is made acquainted with the existence of these specifications and the manufacturers properly label their goods which comply with these specifications, the purchasers will experience no difficulties in obtaining specificationmade goods.

Investigations have revealed the fact that firms manufacturing goods on a mass-production basis are willing to make use of quality-guaranteeing labels, provided only that they can be assured of sufficient demand for goods thus labeled. It is in connection with not only the preparation of suitable specifications, but in the broadcasting of information concerning labeled commorlities that consumer organizations can render a r'cal service to the public.

\section{STANDARDIZATION OF LUBRICATING OILS AND GREASES IN BELGIUM}

The Association Belge de Standardization is submitting to the public a project for the second part of report No. 52, regarding the standardization of methods of sampling and of analysis of lubricating oils and greases, according to information received from Leigh IV. Hunt, acting commercial attaché at Brussels, Belgium.

This project, following the project publisher in September, 1929, concerns the chemical test of oils. It has been drawn up by the same commission during the 11 sessions held between October 15. 1929. and August 30, 1930.
Following the practice adopted by the Association Belge de Standardization, the commission has limited its activity to standardizing the rood methods currently employed by Belgian laboratories for the chemical testing of oils. The commission, therefore, has only considered the determination of the content of saponifiable matter, the index of acidity, the content of asphalt, and the content of ashes. Without misinderstanding the great interest of the test for aging. the commission has not believed itself capable of standardizing this point, since, though there exist a great number of studies on this subject, there is at the present time no method generally accepted by Belgian laboratories. 


\title{
DEVELOPMENT OF NAVY SPECIFICATIONS
}

\section{Navy Department Specifications Aid in Identifying Standard Materials and Subordinate Assemblies}

\author{
By Rear Admiral Wtuldax D. LeAHY, United States Tacy, Chief of Bureau of Ordnance
}

Navy specifications are divided into two main classes: Nary Department specifications and bureau specifications. Nary Department specifications concern themselves with standard material. These specifications are developed by consultation with and by the assistance of commercial manufacturers and are subject to revision as improrements are made or new needs develop. Bureau specifications meet special needs for nonstandard. technical material, such as engines. projectiles, etc. They are developed by experiment and test and are revised from time to time as experience indicates the necessity for revision. Contained in them, howerer. are references to Navy Department specifications to identify standard materials and subordinate assemblies.

A simple illustration will explain the development of a department specification.

The Bureau of Ordnance, in the manufacture of tcclinical ordnance material. uses certain grades of felt. There are at the present time no department specifications for felt, and the Bureau of Orclnance has been requiring samples for test. In order to let bidders know exactly what is wanted, to put them on a fair competitive basis, and to get more biclders interested, the burean desires to have specifications prepared that will describe different grades of felt so accuirately that tests will not be necessary to determine its suitability for the different purposes for which it is used in the Nary. Accordingly an ordnance plant using felt is instructed to draw up specifications corering its needs. The plant consults with felt manufacturers and prepares specifications to cover its rather restricted and special needs.

Using these tentative specifications as a basis, the Bureau of Ordnance draws up in correct form, a proposed Nary Department specification and forwards it to the department specification board, which board is composed of representatives from all the bureaus in the Nary Department. The secretary of this board knows that the Bureaus of Engineering. Construction and Repairs, Aeronautics, and Yards and Docks all requile felt of rarving grades and qualities. So he sends the proposed specifications to all of these bureaus. requesting such comments and additions as will make it cover their needs. Each of these bureans. before making recommendations, consult the felt manufacturers in order to make sure that impracticable or useless requirements are not put into the specification, and that the specifications actually specify what is wanted by the bureau.

\section{One specification drafted.}

Then the board has gathered in proposed specifications corering the needs of all the bureaus. it forwards them to the office of the origin of the proposal, which office combines them into one specification covering all the grades and kinds of felt that are required by the Nary Department. This proposed combined specification is again sent to the bureaus for approval before being printed. The result is a standard Nary Department specification.

Thereafter the rarious bureaus of the Nary Department in ordering felt designate the kind desired by reference to the standard specification. This describes the felt accurately to prospective bidders, who all zet copies of the specifications and who can know exactly what they have to furnish and what tests will be required.

After a time one of the bureaus may derelop a need for felt that is not covered by the specifications, and a rerision becomes necessary. It is not unusual for a manufacturer to say that a specification is discriminatory: that it farors some manufacturers at the expense of others; or an inspector may report that some tests are useless and that others should be substituted for them. All complaints are investigated and, if necessary, corrective revision made, in which new grades of felt are listed and the specification in general is brought up to date. After such revisions misunderstandings are less frequent.

Although Tavy Department specifications are continually undergoing revision, most of them by now have been so worked orer that they corer their subjects thoroughly. 'Their use throughout the Navy is obligatory where practicable, and, as stated above, they are constantly used in bureau technical specifications to specify standard materials and subordinate parts. It is believed that the Nary Department specifications are being extensively used as the basis for many of the new standard Federal specifications now in process of formulation.

\section{STANDARD FOR INTERCHANGEABLE GROUND-GLASS JOINTS RELEASED}

Commercial Standard CS21-30. Interchangeable Ground-Glass Joints, was recently released by the office of the division of trade standards.

This commercial standard governs the taper, diameter, and length of ground-glass joints, so that the product of one manufacturer may be completely interchangeable with that of another. These joints are extensively used for laboratory and inchustrial glassware and the interchangeable nature of these joints greatly facilitates the setting up of complicated pieces of apparatus, and the ready replacement of such parts as may be broken.

A high degree of accuracy in the mannfacture of these interchangeable ground-glass joints is secured by each manufactirer, through the use of working tools that have been checked with standard gages which have been certified as to accuracy against a set of master gages that are maintainer by the National I3ureau of Standards. The joints are marle in nine diameter sizes. ranging from 5 to 50 mm., and all those of commercial standard quality will be labeled by the manufacturer according to size and trade-marked with a designation $\$$, which indicates standarel taper. 


\title{
SIMPLIFIED PRACTICE-A CLEARING HOUSE
}

\author{
Simplification a Means of Clearing Away Nonessentials; Path Then Clear for Standardization and \\ Improvement of Grades, Quality, and Performance of Types and Varieties
}

By Edwin W. Ely, National Bureau of Standards

Every year about this time, when many families move from one house or apartment to another, we hear such remarks as: "I am afraid the curtains I made last spring will not fit the windows in the new place." "Will the big armchair have to be relegated to the attic?" "How about the ice box? It is too good to abandon, and yet it will not fit in the space that has been provided in the new kitchen."

Here is a dilemma. The ice box is an inch too wide. It might as well be a couple of feet. Remodeling of the kitchen is out of the question; rebuilding of the ice box is impractical. The manufacturers of ice boxes and the architects are just as vexed about the matter as the consumer is.

Over a year ago a conference of representatives of the refrigerator industry voted to establish a simplified list of not more than five sets of over-all dimensions, particularly widths, for domestic refrigerators. As a preliminary, however, it was necessary to adopt dimensions for ice cakes, then for ice compartments and door sizes. These two jobs have been carried through to completion by the industry, with the cooperation of the Department of Commerce.

\section{Department of Commerce Cooperates.}

Just how does the Department of Commerce come to participate in this type of work?

Not long ago the average citizen thought of the Federal Government principally as an agent for enacting and enforcing laws, collecting taxes, administering natural resources, and dealing with foreign powers. The Government's many commercial service activities were comparatively little known. Radio broadcasts have had a major part in informing the general public on these regular functions of the Federal establishments.

Early last year Dr. Julius Klein, now Assistant Secretary of Commerce, gave a radio talk on Simplified Practice, Its Meaning and Message. Since that time many industries have become actively interested in the simplification morement and have saved millions of dollars thereby.

\section{Commercial simplification.}

The basic principle of simplified practice is as old as modern business. When a single manufacturer analyzes his market and discontinues the production and distribution of sizes and varieties that are seldom called for that is commercial simplification.

It frequently happens, however, that a single producer can not carry this process to its logical conclusion. He may think it necessary to continue unprofitable items because his competitors are making them. His competitors, however, may be large manufacturing organizations producing many different commodities, the more profitable absorbing the losses caused by those sold in smaller quantities.

Other competitors may not have the facilities for making accurate market analyses. They may desire to cater to local conditions, or to individual preferences of customers. There are a number of possible reasons, but experience has shown that they are rarely so compelling as to prevent a very large part of an industry from joining in a program of reducing unnecessary variety once such a plan is started.

\section{Division of simplified practice.}

The thing needed is some impartial agency with experience in this sort of work, and with the national prestige necessary to command attention and confidence. Such an agency was established by President Hoover while Secretary of Commerce. He set up as part of the National Bureau of Standards a division of simplified practice which operates as follows:

Its activities are purely cooperative. It orders nothing. The request for its services must come from responsible elements of the business dealing with the commodity to be simplified. When such a request is received the industry is invited to form its own committee to study current demand for all existing sizes and varieties. The committee then drafts a preliminary recommendation and presents it for consideration to a general conference of producers, distributors, and consumers. When the conference has approved a final recommendation the division of simplified practice undertakes to submit it to those concerned and, if possible, secure their acceptance.

When sufficient support has been pledged by an entire industry the Department of Commerce lends its prestige by promulgating the simplified-practice recommendation as part of its elimination of waste series. The program comes up periodically before a standing committee of the industry for review, and any desirable revision before it is incorporated in a new edition.

To emphasize the principle of self-government by industry, there is no semblance of Government control. Acceptances of these recommendations create a moral obligation and any departures are referred to the industry's committee for adjustment. The results have been astonishing. For instance, a recent survey to determine the degree of adherence to one of the programs showed that 82 per cent of the acceptors' output conformed with the recommendation. The 18 per cent deriation was caused largely by special orders.

Simplified practice is principally applied to items produced for regular stock. The "special" is on occasion a truly legitimate item, in the judgmgent of the manufacturer and his customer. There are times and situations requiring special treatment. Therefore industry is not asked to commit itself irrevocably to a given list of sizes of any commodity. It is merely suggested to industry that whenever any choice is offered between a standard size and an odd or special size the former be selected.

How many sizes and varieties of abrasive paper and cloth were there a little over two years ago? A few dozen, you say? No; the number was 8,000. The industry was just as astonished as you are. The va- 
riety has been reduced to less than 2,000 in conformance with the purpose just described.

For the same reason 125 sizes of wheelbarrows have been reduced to $41 ; 70$ varieties of shoe goring to 29 ; 16 sizes of shipping tags to 8 ; and 100 sizes of folding boxes for coffee to 2 .

"What other fields offer opportunities for simplification?" you may ask. I may give a few examples of 38 new projects that have been proposed by industry during the past 12 months. For example, there are cheese jars, copper range boilers, floor tiles, sewing trays, bath towels, steel office equipment, and dashboard instruments for automobiles.

All of these concern sizes, dimensions, and immaterial differences only. It is expected that many of these proposed projects will become published simplifiedpractice recommendations. Some, upon closer acquaintance and study by the committees of the respectire industries, may be considered impractical or undesirable for reasons best known to the trade.

\section{Simplified-practice recommendations.}

There are in progress at this moment 25 variety surreys by as many committees appointed by industry. The facts disclosed by these surveys will form the bases for future simplified-practice recommendations. In each case it will be found that there exists a number of varieties for which the demand, if any, is exceedingly small and the production and handling of which simply mean a miscalculation of actual demand that is imposing unnecessary costs on every factor in the situation.

Excess variety complicates the processes of distribution. Six billion fire hundred million dollars is the annual business of 6,000 department stores. This entails an expenditure of $\$ 25,000,000$ for wrapping and packing supplies alone. A study of 34 department stores, situated in various parts of the United States, has recently been completed by the National Retail Dry Goods Association, working through its operating committee on simplification of wrapping and packing supplies, and the division of simplified practice. The acquired data, besides disclosing opportunities for the development of specific simplified-practice recommendations, will bring to the attention of the entire department-store field the best thought and practice in the matter of folding and preparing merchandise for delivery. It is claimed that general use of this information will make possible the saving of many millions of dollars annually.

According to estimates made by industry, the active recommendations are producing annual savings for all interests to an amount exceeding $\$ 250,000,000$. A more general estimate, embracing all activity in simplification throughout the United States, as stated by independent economists, places the yearly savings account at $\$ 500,000,000$.

To cite the experiences of individual manufacturers, distributors, and users of simplified lines of commodities: A year ago, a manufacturer, speaking of the one simplified-practice recommendation he knew best, said quite frankly that 80 per cent of his business came from 2,000 varieties of a particular product. This was but 3.6 per cent of his full line. The other 96.4 per cent, amounting to 53,000 varieties, brought in only 20 per cent of the business. Adherence to the program brought about, among other advantages, a saving in inventory amounting to $\$ 225,223$ and a saving of $\$ 13,500$ a year in reduced obsolescence costs.

A distributor made it known that simplification had enabled him to affect a 15 per cent increase in sales with but 60 per cent of the former range of varieties.

Another dealer claimed that his turnover of stock was more frequent with simplified lines. Previously a turnover of two was about the best he could achieve. Among the direct benefits to the consumer are prompt deliveries, quicker replacement service, lower maintenance costs, and a greater protection against unscrupulous traders.

Briefly, the elimination of needless variety in sizes. dimensions, and types of every-day commodities means a more intelligent utilization of our national resources, more efficient production with lower costs, greater productivity, and hence higher returns to the workmen, and correspondingly greater purchasing power to buy commodities of other kinds. The whole effect is to keep business on a higher level.

As a commercial expedient, then, simplification may be adopted as a means of clearing away nonessentials. The path is clear for the agencies of standardization to improve the grades, quality, and performance of the types and rarieties that are retained in a simplified line. The combined purpose is to develop products that are better-not merely different.

It is one thing to set up a standard; it is another to keep it constantly useful and serviceable. Any standard is of doubtful value until its existence and purpose are generally known and appreciated. By the processes of periodic resurvey and revision it is possible not only to keep the respective simplified-practice recommendations in step with changing conditions but also to determine the degree of adherence that is being accorded them.

For example, 39 existing recommendations were recently resurveyed, 34 of which were reaffirmed without change by the industry and 5 were revised. Examination for adherence in the cases of 25 recommendations showed an arerage degree of adherence of 86 per. cent of all interests.

The work of revision is carried on by standing committees, appointed by the respective industries from among their own ranks, and representing all elements in the industry; a house of representatives, so to speak. These committees have the responsibility of maintaining the simplified-practice recommendations as valuable and useful tools of industry. More than 110 such groups, at present functioning under the procedure of the division of simplified practice, comprise a total personnel of approximately 1.000 representative business men, many of whom are leaders in their particular fields of endeavor.

Later this fall it is planned to hold a general convention of the chairmen of these committees. This meeting will afford an opportunity for the representatives of the specific industries to confer with the planning committee of the division of simplified practice, an advisory body that represents industry as a whole in the development of simplified practice through the Department of Commerce. 'The occasion will afford an excellent opportunity for the exchange of ideas on the broader aspects of this type of waste elimination. It is expected that there will develop sugrastions whereby many industries, working through their respective standing committees. may collaborate in 
promoting stability in the production and exchange of goods.

Broadly speaking, there are three main elements in every industry, the manufacturer, the distributor, and the consumer: No one of these elements can, alone and unassisted, secure the major benefits from simplified practice. All three inust get together, "teamfashion," and, to continue the analogy, "play ball." With all three acting in concert, it is possible to develop simplified-practice recommendations satisfactory to all. Such unity of action should clarify the production policy of industry and permit the concentration of output upon an intelligently developed list. of stock items. Further, it should obviate the danger of placing manufacturing emphasis upon those sizes and varieties which enjoy only an uncertain demand.

The intent is to direct attention of all concerned to the fact that there is a determinable list of items which, because they are specified so selflom, represent "frozen" capital that might be released for proinctive purposes.

That industry has been consistent in its belief in simplification as a useful tool for management is at- tested by the large number of individual companies, institutes, societies, and associations which have recorded with the Department of Commerce their approval of the movement in reneral and of specified simplified-practice recommendations. 'The lists of acceptors form an indispensable part of every published recommendation. Business organizations in all parts of the country appear in those lists.

Intelligently applied simplified practice does not in any way operate to retard progress in industry, but rather concentrates effort upon the best thought and practice. Closer attention can be given by inventors, scientists, technical experts, and manufacturers to the improrement of the remaining varieties. When worth-while developments occur in connection with a commodity covered by a simplified-practice recommendation full cognizance of them may be taken when that recommendation comes up for periodic revision.

It is clear that simplified practice benefits every factor in our American economic life. It is a movement that each of us will do well to understand and to promote to the best of our ability.

\section{INCREASE NOTED IN TESTING WORK}

Bureau of Standards Schedule Shows Increase of 27,214 Items Tested During Fiscal Year

An increase of 27.214 in the number of items tested at the National Bureau of Standards during the fiscal year 1930 as compared with 1929 , and a corresponding increase in the fee ralue of $\$ 139,212$, has been announced by the director of the bureau. A comparison of figures for 1928 and 1930 shows increases for the latter year of 68,513 and $\$ 218,497$. 'The total number of items tested during 1930 was 200,726 and the fee valie $\$ 683,61451$.

These figures are particularly interesting at this time, since they show a steady increase in the work of the Govermment's laroest testing laboratory during a period when business in general has decreased and when one would naturally have looked for a decided drop in general testing.

The bureau's statistics cover 46 different items or classes of tests. During 1930, as compared with 1929 . there were increases registered under 26 of these items while in 20 cases the number of tests decreased In the matter of the fee value, increases were noted in 28 cases, in 2 cases the fee value did not change. while in 16 cases the fee ralue decreased.

The greatest single increase of 1930 , as compared with 1929 , was in clinical thermometers. where an increase of nearly 24,000 occurred during the year (total number tester, 100,648). Large percentage increases were also recorded in eletric hatteries, miscellaneous limensional determinations, aircraft engines, engineering materials, cement, and ceramic materials. In comparing 1928 and 1930. important increases have taken place in electric batteries, electric lamps, dimensional. determinations, weights and balances, rolumetric apparatus, hydrometers, laboratory and clinical thermometers, radioactive materials, ceramic products, and in the distribution of standard samples.

Roughly, two-thirds of the burean's test work is for the fiederal and State Governments, while one- third is for the general public. Although the latter class of tests decreased about 14 per cent in 1930 , as compared with 1929, there was still an increase of 17 per cent as compared with 1928 . This is a rery satisfactory showing and proves that the value of carefully conducted tests is becoming more generally appreciated.

\section{ITALIAN STANDARDIZING SOCIETY FORMED}

\section{New Organization Known as "UNI"}

The National Organization for the Creation and $\mathrm{Ob}$ servation of Recognized Standards in Industry and 'Trade in Italy, which has been in contemplation for' more than two years, has now been definitely established by a royal decree dated July 18, 1930, and published September 4, according to information received from Mowatt M. Mitchell, commercial attaché at Rome, Italy. The organization is to be known as the Ente Nazionale per I'Unificazione delle Industrie, and will be commonly known as the UNI. The objects of the organization are stated as follows: $(a)$ To standardize methods and procedure for industrial production and for the sale of its products; $(b)$ to establish standard types of tools, instruments, machinery, and parts; and $(c)$ to promote the understanding and the adoption of these standards.

In carrying out its purposes the UNI is authorized to establish connections with similar foreign organizations. Membership in the organization is extended to all the various branches of the National Confederation of Industry and to other technical, scientific, professional, and economic organizations who may be interested in standardization. Membership in the UNI will cost each such organization a minimum of lire 25,000 $(\$ 1,309)$ per year, which will entitle the contributing organization to a seat on the directorate, and additional seats may be had for each additional contribution of lire $50,000(\$ 2.618)$ per year up to five. 


\title{
STANDARD RAILWAY-TRACK SCALES FOR LIGHT INDUSTRIAL SERVICE
}

\author{
Résumé of Specifications Presents Possibilities of Single Weighing of Freight
}

By Hanre M. ToEser, National Bureall of Stamdards

In round numbers, steam transportation systems in the Enited States accumulate $\$ 4,500,000,000$ of revenue per annum for handling freight in carload lots at the average rate of $\$ 1.98$ per measured ton. The primary instrument of measurement is the rail road-track scale. of which 9,000 are in use for this purpose.

In the chain of circumstances between raw material and finished products, most articles of commerce are measured over track scales for the purpose of fixing intrinsic values at unit rates. Thus, not only in the transportation industry but in all channels of commerce the majority of the wholesale barter of commodities depends primarily upon the track scale for fixing costs. The intimate relation with the transportation industry, however, is principally the concern of this article.

In the abstract measurement of roods is essential to ccononic exchange; but since the operation increases the cost of goods without improving their adaptability to human needs, measurement, necessary though it may be, is nevertheless an economic evil. Efforts are being made either to reduce the amount of measurement or the cost of doing it to a minimum. 'That axiomatic principle apparently was not given adequate consideration in the early growth of our transportationsystems, and now in the press of competition the consequences are being felt.

In particular, a common transaction in a carload of goods nominally requires three weichingsone by the consignor for use in invoicing, one by the carrier to establish freight charges. and one by the consignee to check the invoice and for protection against shortage in (leliveries or loss in transit. Elimination of one or more of these weighings is the modern tendency.

The carriers disclaim responsibility for weight determination between buver and seller. This stand is perhaps impregnable. judged from ordinary rules of business, but at the same time it positively roids the possibility of the most economical procednic of getting weighing done. The practice of establishing husines: transactions in carload lots upon one weighing is held to be somnd and is actually followed in some comntries. 'This is to be done by the carriers. who might perform the service at tariff rates which would enable them to gnarantee the accuracy of the transaction between buyer and seller.

Speed, the watchword in American railroarling, is the outstanding inhibition to establishment of the practice here. Weighing does complicate railroad operation and (loes slow up deliveries. Then too, Imeri('an business practice requires that goods be weighed as closely as possible to the point of origin in order that invoices and bills of lading may be effectively handled.

\section{Recent changes in weighing practice.}

Based on the fundamental principles that weighing freight complicates railroad operation, and that it munt be rlone as near to the point of origin as possible. a decided change in weighing practice has come about jn recent years. This involves a so-called "weight agreement" between shipper and carrier whereby the carrier accepts the weight for freight billing purposes as determined by the shipper over his own scale with the proriso, that the carrier shall at intervals authenticate the scale performance is circumstances require by methods of test which the carlier consider's adequate.

'Thus the shipper obtains a weight for invoicing and the carrier a weight for establishing freight charges in one operation. Obriously this practice reduces the amount of weighing. How effective it is, in that respect, may be judged from the fact tlat since 1926 roughly 25 per cent of the railroarl-owned track scales in use at that time have been abandoned or taken out of service.

The turn of events just mentioned and other lesser complications, whose number and variety forbic description here, brought about an acuteeconomicsituation : the alleviation of which is the - purpose of proposed specifications for railway track scales for light industrial service. 'To what degree they will relieve it is uncertain; but this is certain, if they do not adequately do so, further radical changes in the determination of consignments of carload freight are due, or else carriers must reve:t to weighing. 'Tendencies which gain headway in a ponderous machine, such as the transportation inclustry. nsually go too far and may become ricions before they are checked. That this has occurred with respect to the practice just mentioned is not altogether impossible.

\section{Summary of situation.}

Briefly, the situation is as follows: In 1920 specifiations for weighing machinery for the transportation industry were promulgated and nltimately became the formal construction standard. I weigliing machine built to conform to those specifications. requires a disproportionate mupoductive (ap)ital investment for many individual industrial plants who, in the agoregate, fumish a rery great popoltion of freight, indeed. to the transportation industry Again, a quite remarkable change in public demand. for accuracy of weighing lats comer to pass, as illoc- 
trated in the per cent intolerance curve which summarizes the track-scale testing work of the National Bureau of Standards for the past 16 years.

The reader will note that the curves in the illustrations are virtually flat from the date 1927 forward, indicating that a peak has been reached. This state of affairs, although it has been maintained for three or four years, can not reasonably be expected to continue indefinitely. As a matter of fact, the peak has

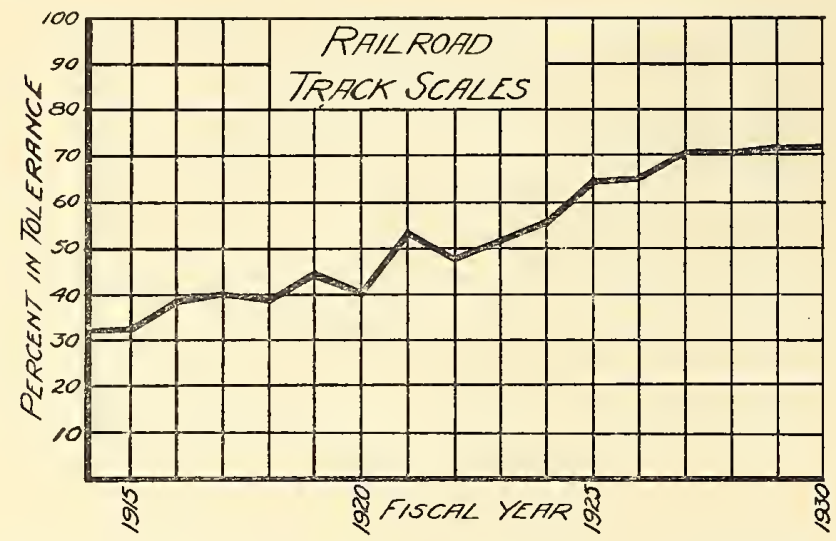

been reached at too low a grade of performance. What, therefore, is desired is further improvement.

The following facts indicate, however, that a hope for improvement based on past and present conditions is vain. Comprehensive records of installation dates show that the average industrially-owned railroad track scale was installed in July, 1921. Under average conditions of maintenance an average life of nine years for a railroad track scale is too long. Records of sales informally obtained show that the annual substitution of new equipment is less than 2 per cent of the total amount in use. This indicates that the average track scale will have to endure, with more or less periodic rejuvenations-nine or more years apartfor a period of about 50 vears. Vague as these indications may appear they do have a foundation in fact, and their purport is that, without remedial measures, a decline in the quality of weight measurement in American commerce is inevitable.

Naturally since the burden of weighing is being shifted to the industries, the matter of furnishing adequate weighing machinery within their means becomes pressing. Essential to the orderly production and distribution of such machinery are construction standards that bear the formal stamp of approval of the involved interests. To this end the interests were coordinated, and by cooperative effort such formal specifications were evolved. The specifications, sponsored through the various stages of formation by the National Scale Men's Association ${ }^{1}$ and shortly to appear as a formal publication of the National Bureau of Standards, seek to establish a track scale of minimum cost that will meet public demands for accuracy and durability. An added necessity, as a regulatory feature, is limiting the distribution of the new type of scale to the intended service. This end was songht by placing limits on the size and capacity which make

1 The National Scale Men's Association, C. L. Richard, secretary, 5800 West Sixty-ninth Street, Clearing Station, Chicago, 11 . impossible the handling of cars which ordinarily do not find their way into light industrial service.

\section{Unique features of scale.}

The unique features of the scale are 46 feet weigh rail length and 180,000-pound weigh beam capacity. In other respects the specifications differ from others now in effect chiefly in the dimensional detail essential to economical design. At first sight it would appear to the initiate perhaps that a 46 -foot weigh rail length is a handicap to practical use. Such, however, is hardly true. Of the railroad-owned track scales now in service, over 45 per cent have weigh rail lengths of 46 feet or less. The weigh beam capacity of 180,000 pounds seems light until one considers that the average loaded freight car in the United States carrying slightly less than 70,000 pounds has a gross load of approximately 110,000 pounds and that the 50-ton open-top car, extensively used for the distribution of coal and mineral products to industrial plants, has a rated gross load of 169,000 pounds.

True it is that the coal and mineral handling roads operate cars whose wheel base and gross lading can not be handled by such a scale. These cars, however, move in restricted lanes, such as mine to seaboard or lake front, and are practically limited to such movements by conditions of power, roadbed, or nature of the commodity handled. In all these cases, however, the question of providing proper weighing facilities hardly appears to reach proportions that require regulatory attention. It so happens that alert management, promptly recognizing the need for being sufficiently capitalized, hastens to provide the necessary facilities.

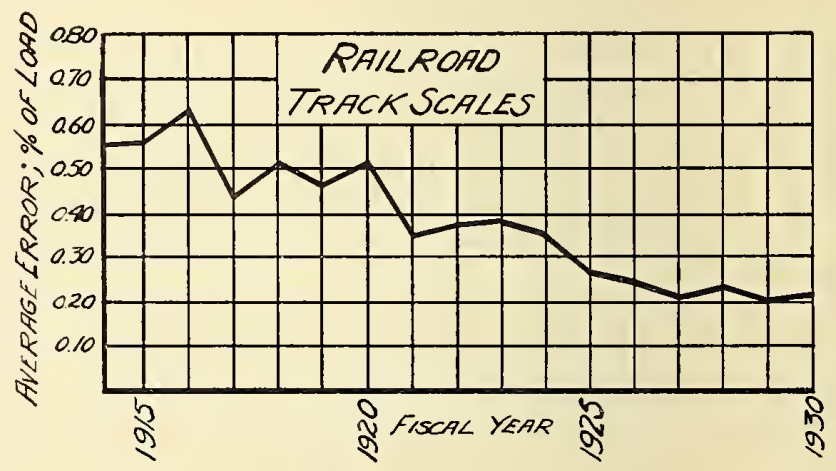

\section{Index to marketing possibilities.}

As an index to the marketing possibilities of the new scale, the following table prepared from the latest Interstate Commerce Commission report ${ }^{2}$ may be reviewed:

\begin{tabular}{|c|c|c|}
\hline Commodity group & $\begin{array}{l}\text { Tons per } \\
\text { loaded car }\end{array}$ & $\begin{array}{c}\text { Percentage } \\
\text { of total } \\
\text { originating } \\
\text { freight }\end{array}$ \\
\hline $\begin{array}{l}\text { va } \\
\text { Products of agriculture } \\
\text { Animals and products } \\
\text { Products of mines } \\
\text { Products of forests } \\
\text { Manufactures and miscellaneous }- \\
\text { Less than carload freight }\end{array}$ & $\begin{array}{l}24.56 \\
11.85 \\
51.49 \\
28.38 \\
26.37\end{array}$ & $\begin{array}{r}9.55 \\
1.94 \\
52.27 \\
7.93 \\
25.63 \\
2.68\end{array}$ \\
\hline
\end{tabular}

2 Interstate Commerce Commission Statisties of Railways in the United States, 1928. This statement is taken from statement No. 28. 
Of the above commodity groups, "products of agriculture," which consists chiefly of grain, is the only one whose possibilities as a market field for the new scale is positively limited. Track scales for weighing grain are covered by existing specifications. "Products of mines" is limited to the extent that the scale can not be effectively used for those parts that do not move in 50-ton capacity or less, open-top cars. That 50 per cent of all originating freight can be handled over the new specification scale appears to be a conservative estimate.

In order to avoid the risk that critical attention may be wasted on something less important, the conclusion may properly consist of the following blunt statement of facts: A climax in the development of American business has been reached; to prevent deterioration of one of its fundamentals, namely, the wholesale measurement of goods, relief must be brought to that part where the burden has been shifted; means must be provided that will make possible the rapid substitution of new weighing machinery for that which is obsolete and makeshift. Such, simply, is the purpose of the specifications for railway track scales for light indus. trial service.

\section{CURRENT ACTIVITIES OF AMERICAN MARINE STANDARDS COMMITTEE}

\section{Committee Reviews Status of Pending Proposals for Standardization}

The following current information relating to developments in certain standardization projects under the auspices and procedure of the American Marine Standards Committee, has been furnished by that committee.

The executive board of the committee will meet November 15 , in the office of the chairman, Col. E. A. Simmons, 30 Church Street, New York, N. Y. This will be the last meeting of the present board. Election of the executive board for 1931 will take place in December.

Proposed standards for cleats for ships, tentatively approved by the technical committee on hull details, have been submitted to the membership and others concerned for critical comments and suggestions. It is expected that the ballot vote will be sufficiently complete for repolt of results to the executive board at the meeting on November 15, with proposal to promulgate the standards.

Proposed standards for bollards and cleats for docks, tentatively approved by the technical committee on port facilities, have been voted on by the memberships of the American Marine Standards Committee and the American Association of Port Authorities. The results are to be reported to the executive board at the November meeting with proposal for promulgation of standards.

\section{Technical activities.}

The following proposed standards are under consideration by the technical committee on hull detail:

Ladders and gratings.-Comprising metal ladders of simple construction for service access in machinery spaces and other ship compartments; also on superstructures and deck erections; companion ladders of wood and metal and their handrails; machinery grating used as platforms; landings and walkways in machinery spaces; and grab rungs which are used in lieu of ladders where permanent steps are required for occassional access.

External fixed and hinged lights.-Comprising four distinct types of circular glass lights fitted in ship) sides to obtain daylight or ventilation in various compartments, namely, fixed light, which is of the nonopening type; hinged light with hinged cover, the latter being a shutter to close the opening-especially in rough weather-against the possibility of the glass disk being broken; hinged light with portable cover, this type being generally identical with the preceding, but intended for locations where the application of the shutter is less frequent; hinged light without cover, for use only in superstructures or sheltered places. The proposed standards include suggested methods of locking the lights or covers in closed position under authority of the commanding officer of th: ship in compliance with the regulation of the International Conference for Safety of Life at Sea.

The following proposed standards are under consideration by the technical committee on port facilities :

Platfom cargo stings.-Used for lifting cased cargo from ship to dock or vice versa. Tro sizes proposed are, namely, 3.5 by 6.5 feet, and 3 by 6 feet. They are provided with adjustable angle plates on the rope slings to protect the outer corners of the top row of cargo cases against cutting or crushing by the rope slings.

Cargo mast for docks.--T0 feet high, 5 feet 4 inches square at the base, and 2 feet square at the top. These are latticed steel angle bar structures. They are installed on open docks at various intervals on a line parallel to and at a sufficient distance from the edge of the dock to allow one or more railroad tracks. They are used to attach cargo-handling tackles from the ship so as to transfer cargo from the latter to railway cars or to the dock, or vice versa, in conjunction with the ship's cargo gear.

\section{Publications.}

'The committee's publications, known as the A. M. S. C. series of the Department of Commerce, now number 75 . A list of these publications is available 11 pon application to the secretary of the American Marine Standards Committee. Room 713, Commerce Building. Washington, D. C. Copies are obtainable at nominal prices from the Superintendent of Documents, Government Printing Oflice. Washington, D. C. 


\title{
TILE INDUSTRY REDUCES COST OF MANUFACTURE THROUGH STANDARDIZATION
}

\author{
Industry Finds Standardized Models Reduces Overhead by 20 Per Cent
}

By MILTON J. l'HiLIIPS

Writh 20 per cent pared from overhead charges, the tile industry of the Tnited States, under the leadership of the Associated Tile Manufacturers, is encouraged to strip its product of all excessive patterns and sizes and indefinite terminology. To date, 735 patterns and sizes have been cut to 115 and a dozen standards of quality have been reduced to three. Similarly, all indefinite words in tile terminology have been banned like the now-obsolete patterns. The effect is one of indescribable relief, according to the enthusiastic testimony of participants in the movement to simplify and standardize this growing indlustry.

Prior to the bold slashing of patterns several years ago every tile manufacturer in America was involved in a neck-and-neck dash to reach the wire first with the latest in new slesigns. 'Then. if one rentured to supply the tile for new jobs, it was usually necessary that he get up more new designs, and what was true of one manufacturer was at times true of all manufacturers. Literally thousands of dollars of busy capital were buried deep in financing patterns and sizes that were practical duplicates among a mass of stock.

To make the outlook increasingly gloomy there was an undoubted acceleration in the movement to turn out new designs, in some cases amounting to nothing more than a mere matter of a slight fraction of a degree in a specified curve on a small cap piece.

Formerly, before setting down the final tile specifications, an architect called in a tile contractor in preference to wading through from 10 to 20 catalogue: with vague and varying descriptions in an admittedly faulty nomenclature. It is obvious that the contractor indicated certain patterns with which he was most familiar. Almost instant production of these same patterns by competitors was absolutely necessary.

Certain manufacturers preferred to keep their products out of the bidding rather than incur an excessive burden of expense in making new models, a practice that they demurred against generally because it left the field to one or two competitors who were free to demoralize the industry and cheapen the quality of the product. It was not uncommon for a contractor to bid low with the evident intention of diluting the shipment with a suflicient number of inferior tile to even up, a policy easily possible because of the lack of uniform specifications and trade terms.

To confuse the customer further. printed matter on shipments was frequently in code, and the sufferers were not the customers alone. Clear-headed manufacturers, who were struggling to build enduring reputa- tions for fair dealing, were victims of the practice. 'The reputation of the industry, too, was at stake. Of course, the dealers who were guilty of substitutions and other subterfuges indicated that they were jealous of the fair name of the industry by laying inferio: tile in shadowy places as far as possible from strong light.

In 1918, 13 manufacturers decided to put up with the intolerable conditions no longer. They had cooperated with one another in certain studies looking to news uses for tile, and it was not hard to agree on a program of drastic cutting. They were ripe for it. By resolution they appointed a commission with authority to call into comsultation architects, designers, and factory experts and after exhaustive study to slash and slice fearlessly. The knife appeared to be the only sure hope, no matter how mercilessly it might be used. and, like a body of skilled surgeons, that commission studied the patient-the tile industryfor 18 months.

Then came the diagnosis and the treatment. Eacli manufacturer stuck the knife deep into his own catalogue. Six hundred and twenty ( 84 per cent) models had been adjudged obsolete. Some manufacturer's had more of the banned models than other manufacturers, but every catalogue had enough of them to stamp its owner a virtual martyr to the future of the industry. It was a bewildering amount when the commission announced its findings, for, aside from the possible loss of business, the 13 watchful competitors saw the handwriting on the wall. Henceforth, they could compete in quality and price only and never again vie with each other in design. It was a tense moment, but the outlook was uppermost in their resolute thought.

When those men returned to their plants the change to a simplified and standardized practice was accomplished by a gradual elimination. They were stocked more or less heavily with the now obsolete models; their dealers carried them; new constructions were under way with obsolete models partly installed, and there were the usual replacements to be taken care of. All of these parties must be protected from hardships. Their customers (the public) must be adequately provicled for. Likewise, dealers' stocks could not be scrapped instantly unless manufacturers liquidated the losses. Their own losses, too, would have been heary in such a contingency. Therefore, it was left to the judgment of the 13 men in that now famous conference to carry out the new policy as rapidly as it was humanly possible.

After several year's' effort 620 obsolete patterns are rapidly disappearing and factories are getting into 
full swing unhampered by dead duplicates that in the old days needlessly clogged production. Although production has been greatly accelerated, there has been ample time to check adrantages and disadrantages of the new practice. 'There appears to be but one voice, of course, it is many voices in mison, and they say the advantages far outweigh the disadvantages. In fact, it is doubtful if there are any disadrantages. Decreased stocks; decreased production costs, as indicated by the 20 per cent lowered selling overhead; the doom of substitutions; and better understanding between the public, the manufacturer. and the contractor; these are the things that one hears in the offices of the partics concerned.

However, another huge task awaited solution of the first. The industry found itself on that historic day facing a new sunrise and new difficulties. Thirteen large manufacturers began preparation of new catalogues. 'The patterns and sizes would be alike, but hitherto each man had a technology peculiarly his own. It is true that the physical appearance of the terms may have seemed similar, but different offices had various meaning. Henceforth, there must be uniform trade terms with uniform trade meanings for the customer, the contractor, and the manufacturer, whether in Alaska, Oregon, Pennsylvania, or Florida. Two tandardizations-one of models the other of trade terms-suddenly became imminently necessary.

'Through the offices of the division of simplified practice of the National Bureau of Standards, there was developed Simplified Practice Recommentation No. 61, which covers the following classifications: Standardized models, grades, names, sizes, and packages for the industry as a whole.

It is obvious that this mighty stricle in the interest of character in an industry could not have been aceomplished by a single manufacturer for the reason that his efforts would have suffered sadly from misinter"pretations and impositions. 'The consumption of this excellent example of effective cooperation among alert competitors was not the work of a day, a month, or a year. The welding began with joint in vestigations of important questions of markets and new and better nses of tile, and the like. It might also be said that it began when a recognition of a new principle of business-that of fair play-began to cast its warm glow across the thought of great leaders in the tile industry.

Subsequent development was gradual-evolutionary-slowly at times, more rapidly now and again, tusing a morale, an esprit de corps, that flowed in this decision to simplify both models and nomenclatureto standardize-to do away with costly perplexities that were sapping the vitality of the industry.

\section{NINETY-SIX STOCK SIZES OF TURKISH TOWELS WILL BE REDUCED TO SIX}

$A$ greneral conference of representatives of manufacturers. distributors, and nsers of Turkish towels, recently held under the auspices of the National Burean of Standards, at the offices of the Cotton T'extile Institute in New York City, unanimonsly adopted a implified practice recommendation for that product.

It was the opinion of those attending the conference that the manufacture of fast selvaged Turkish towels for stock be reduced to six sizes. The sizes, given in inches. are as follows: 16 by 30.18 by 36,20 by 40.22 ly 44.24 by 46 , and 24 by 48 . The recommendation iloes not apply to special sizes made in conformance with particular orders for items other than stock. or to sizes smaller than 16 by 30 inches, and larger than 24 by 48 inches.

This simplification is based on a survey of sizes reported as being prodnced during the year 1029. which indicated that these six sizes would fully satisfy the requirements of all normal purposes for which 96 sizes vere made in that year. The program, subject to approval by the inclustry, is to be effective from March 1. 1931.

\section{RECENT ECONOMIC EFFECTS OF SIMPLIFIED PRACTICE}

Improved Management Depends on Greater Application of Simplified Practice

"The most recent phase of simplification has been a decided quickening of interest on the part of consumers," according to George $\mathrm{A}$. Cooper, a member of the staff of the National Burean of Standards. in an article prepared by him entitled " Recent Economic Effects of Simplified Practice." Mimeographed copies may be obtained upon request to the bureau.

"There five years ago nearly all simplified practices recommendations were initiated by manufacturer's and brought to the purchasers and distributor's for approval or modification." he states, "there are simplification programs developed to-day at the suggestion of purchasers."

Specific examples cited to support the assertio: that consumer's demand for simplification is a recent economic change are to be found in the completer simplified practice recommentations on classification of iron and steel sclalp): bank checks, notes, drafis, and similar instruments: commercial forms (invoice. inquiry and purchase or (ler) : and the proposed simplifi. cation of repartment store wrapping and packing supplies.

In concluding his article the writer states. "If you want to keep pace with progress. if you want to apply scientific management, if yon want to effect a recluction of inventolies, reduce orerhead expenses. cut cost of oferation, render better service, obtain quicker deliveries, benefit by case and convenience of installation, and help your company meet competition successfully, then your, as a consinnel' must recognize and interpret the relation of simplified parctice to the commodities used by you or by your or wanization."

Means by which all interests, that is, the manufareturer, distributor, and consmmer, are mutually benefitted though their participation in national simplified practice programe have also been developed in this allicle. 


\title{
CURRENT ACTIVITIES OF THE AMERICAN STANDARDS ASSOCIATION
}

\author{
Association Announces Approval of Several Codes and Standards
}

The following current information relating to developments in certain standardization projects under the auspices and procedure of the American Standards Association has been furnished by that association:

\section{Code for pulverized fuel systems.}

The rapid increase in the use of pulverized fuel, accompanied by the derelopment of new methods and equipment, has made necessary the revision of the "Safety Code for the Installation of Pulverized Fuel Systems," originally approved in 1927. This revision, carried out under the joint sponsorship of the National Fire Protection Association and the United States Department of Agriculture, has now been approved by the American Standards Association.

The code covers the construction of buildings housing fuel pulverizing equipment, the ventilation of these buildings, and specifications for dust collection systems. Methods of preventing explosions through static, through the drying of coal, and through its transportation through pipe lines, are included in the code. The code also contains suggestions for safe operating rules to be printed on instruction cards which can be used for the guidance of employees in charge of the operation of such systems. The standard is one of a group covering various types of explosion hazards. Other codes in this group which have already been approved include: Pulverizing systems for sugar and cocoa, prevention of dust explosions in starch factories, in fiour and feed mills, and in terminal grain elevators.

\section{Standard for coal-mine tracks.}

The standards council of the American Standards Association has approved the scope of the project for the revision of the American tentative standard "Coal Mine Tracks, Signals, and Switches." The American Mining Congress is sponsor for the project.

The project will cover standardization of coal-mine tracks and signals, including switches, wood and metal ties, and other items of track construction, together with recommendations of efficient installation and maintenance practices.

\section{Dry cells and batteries.}

Under the sponsorship of the National Bureau of Standards, specifications for dry cells and batteries have been revised, and the revision has now been approved by the American Standards Association with the status of American standard. The principal differences between the revised standard and the preceding edition consist in the increase in the performance requirements as expressed in the following tests: Heavy-load intermittent tests, light-load intermittent tests, continuous tests, and delayed-service tests of 3,6 , and 9 months' duration. 'The revised specifications cover definitions, nomenclature, types, standard sizes, materials and workmanship, jackets, marking, sealing compound, terminals and cell connections, voltage tests, capacity tests, and performance requirements for dry cells and batteries for radio, telephone, ignition, flash light, and other uses.

\section{New American standards published.}

A list of standards, which have been approved by the American Standards Association and have recently been published by the respective sponsor organization, is given below. These standards are available for loan or purchase through the American Standards Association, 29 West Thirty-ninth Street, New York, N. Y.

AII-1980, Code of Lighting; Factories, Mills, and Other Work Places.

ZrOd-1930, Symbols for Photometry and Illumination.

B29a-1930, Roller Chains, Sprockets and Cutters.

B7-1930, Safety Code for the Use, Care, and Protection of Abrasive Wheels.

B3-1930, Ball and Roller Bearings.

B5e-1930, Dimensions of Cut and Ground Taps.

B5c-1930, Nomenclature of Milling Cutters.

BISc-1930, Slotted Head Machine Screws and Wood Screw Heads.

Z10e-1930, Aeronautical Symbols.

M11-1930, Recommended Practice for the Use of Explosives in Bituminous Coal Mines.

OI-1930, Safety Code for Woodworking Plants.

ZIIk-1930, Method of Test for Distillation of Natural Gas Gasoline.

7IIu-1930, Method of Test for Detection of Free Sulphur and Corrosive Sulphur Compounds in Gasoline.

\section{Testing petroleum products.}

Revisions of nine methods of test for petroleum products and lubricants have been approved by the American Standards Association. These revisions, submitted by the American Society for Testing Materials, as proprietary sponsor under ASA procedure consist, for the most part, of minor changes.

The American standard for methods of test for water in petroleum products, which is recommended for use with crude mineral oils and fuel oils, has been revised in order to take advantage of greater accuracy of scale divisions and markings of the pear-shaped tube and cone-shaped tube previously adopted. The niethod of test for water in petroleum products and other bituminous materials was revised in wording only, to make the description of the standard method entirely clear.

The revised American standard Method of Test for Distillation of Gasoline, Naphtha, Kerosene, and Similar Petroleum Products, clarifies the procedure in determining the maximum distillation temperature or end point and specifies that "the volumes of the distillate collected shall be observed and recorded when the melcury of the thermometer reaches each point that is a multiple of $10^{\circ} \mathrm{C}$. or the Fahrenheit equivalent."

The revised American standard, Method of Test for Distillation of Natural Gas Gasoline, clarifies the procedure for determining the maximum distillation cemperature, accuracy, and making the correction for barometric pressures not lower than $735 \mathrm{~mm}$ of mercury.

The revised American standard, Method of Test for Burning Quality of Kerosene Oils, and the American standard, Method of Test for Burning Quality of Minel'al Seal Oil, make it possible to utilize apparatus now arailable without affecting the results of the tests. The revised standard. Method of Test for Burning 
Quality of Long-Time Burning Oil for Railway Use, includes a table of the test burner dimensions and chimney.

The revised American tentative standard, Method of Test for the Determination of Autogeneous Ignition Temperatures, covers minor details affecting the solder bath and asbestos shield and a clarification of the procedure.

The American tentative standard, Method of Test for Cloud and Pour Points for Petroleum Products. has been clarified but not changed in technical content.

The American tentative standard, Method of Test for Melting Point of Petrolatum, was slightly modified to include in the specifications " a transparent container of not less than $500 \mathrm{~mm}$ capacity that will permit the immersion of the test tube to a depth of at ieast $75 \mathrm{~mm}$ and still leare a depth of $15 \mathrm{~mm}$ of water below the bottom of the test tube." The rate of increasing the temperature of the bath was increased.

Insulator tests and ratings.

A new American standard, Insulator 'Tests and Ratings, developed under the sponsorship of the American
Institute of Electrical Engineers and the National Electrical Manufacturer's' Association, has just been approved by the American Staridards Association.

The standards is not to be interpreted as forming complete insulator specifications, but rather as defining the methods of making the various tests described when they are required. The standard specifies design and routme tests for pin and suspension insulators. These comprise tests for dry flashover voltage, wet flashover roltage, puncture voltage, and combined mechanical and electrical strengths. Pin insulators are rated according to dry flashorer and wet flashover voltages expressed in kilovolts. Suspension insulators are rated according to dry flashorer and wet flashover voltages expressed in kilovolts and also according to combined mechanical and electrical strength. The testing equipment and method of measuring voltage are required to conform to the standards of the American Institute of Electrical Engineers. In an appendix to the standard a method of discussion of the variation of wet flashover voltage with water resistance is given.

\section{STATUS OF FEDERAL SPECIFICATIONS}

Fifteen Revisions, Five Proposals, and Four Promulgations

Fifteen Federal specifications have been submitted to interested elements for revision, five proposed specifications have been submitted, and at the same time four approved specifications have been promulgated, according to the Federal Specifications Board. The revisions and proposed specifications are now before the Gorelnment departments and others interested for comment and criticism.

These specifications also bear the new designation in accordance with the system used in the Federal Standard Stock Catalogue. Copies of the specifications or further information concerning them can be obtained from the Federal Specifications Board, National Bureau of Standards, Washington, D. C.

SPECIFICATIONS UNDER REVISION

\begin{tabular}{|c|c|c|}
\hline $\begin{array}{l}\text { F. S. } \\
\text { No. }\end{array}$ & Commodity & $\begin{array}{l}\text { New designa- } \\
\text { tion }\end{array}$ \\
\hline $58 \mathrm{a}$ & Batteries and cells; dry... & \multirow{9}{*}{$\begin{array}{l}W-B-101 \\
\text { DD-G-451. } \\
\text { O-F-351. } \\
\text { SS-P-401. } \\
\text { SS-P-431. } \\
\text { SS-C-181. } \\
\text { SS-W-101. }\end{array}$} \\
\hline 123 & Glass; flat (for), glazing purposes & \\
\hline 124 & Fire-estinguishers; chemical, hand & \\
\hline 247 & Plaster; gypsum & \\
\hline 285 & Plaster-board; gypsum . & \\
\hline 443 & Cement; masonry ... & \\
\hline $444 a$ & $\begin{array}{l}\text { Waterproofing material; integral, water-rcpellant type (for } \\
\text { use with Portland cement, mortar or concrete). }\end{array}$ & \\
\hline 454 & $\begin{array}{l}\text { Coarse aggregate for Portland cement concrete pavement or } \\
\text { base (crushed stone, gravel, or slag). }\end{array}$ & \\
\hline 464 & $\begin{array}{l}\text { Fine aggregate for Portland cement, concrete parement or } \\
\text { base (sand, etc.). }\end{array}$ & \\
\hline $\begin{array}{l}479 \\
495\end{array}$ & $\begin{array}{l}\text { Frames, hack-saw } \\
\text { Pipe; concrete, plain }\end{array}$ & \multirow{5}{*}{$\begin{array}{c}\text { GGG-F-671. } \\
\text { WW-P-371. } \\
\text { W-G-101. } \\
\text { VV-MI-571. } \\
\text { Do. } \\
\text { Do. }\end{array}$} \\
\hline $622 \mathrm{a}$ & $\begin{array}{l}\text { Pipe; concrete, plain } \\
\text { United States Government motor gasoline. }\end{array}$ & \\
\hline 623 & Motor fuel $F$ & \\
\hline $\begin{array}{l}623 \\
623\end{array}$ & 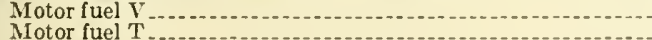 & \\
\hline & 1. & \\
\hline
\end{tabular}

PROPOSED SPECIFICATIONS

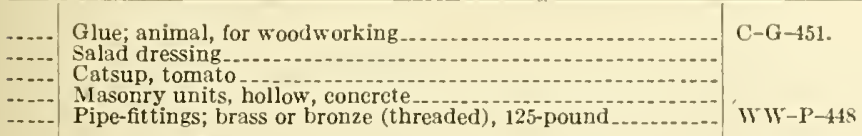

SPECIFICATIONS PROMULGATED

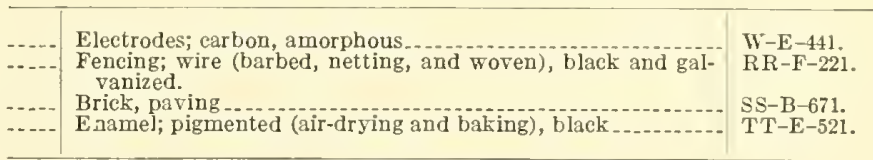

\section{CERTIFYING HARDWOOD AND SOFTWOOD LUMBER}

By far the most elaborate, and perhaps the most effective, application of the certification and labeling plan is being made to Federal specifications Nos. 24 and 533a, for hardwood and softwood lumber. Requests to be placed on the willing-to-certify lists have been received from 794 hardwood lumber manufacturers, 871 softwood lumber manufacturers, and 143 wholesale dealers in softwood lumber.

The lists of manufacturers and wholesale dealers, which will probably contain the names of more than 2,000 willing-to-certify firms, will be sent to all known American retail lumber dealer's. Finally, lists of willing-to-certify manufacturers, wholesale and retail lumber dealers will be arranged as "sources of supply" of softwood lumber" complying with American Lumber Standards and hardwood lumber complying with the grading and inspection rules of the National Hardwood Lumber Association and distributed to public purchasing officers. In this work the National Bureau of Standards is receiving the thorough cooperation of all the nationally recognized associations representing the lumber maufacturers and dealers. Several of the lumber manufacturers' associations are organized to supervise the certification and labeling (grade marking) of member firms. 


\section{STANDARDS IN THE MANUFACTURE OF FISH MEAL}

\section{Uniform Production Methods Increase the Utilization of Waste Products}

By Roger W. Harrisox, Associnte Technologist. Burcan of Fisherirs

The fishing industry, like many other industries, is giving increased attention to the utilization of its waste products, including those materials, from which fish meal may be manufactured. Unfortunately, too little attention has been given to uniform production methods, and there now exists in the industry a need for information which will lead to simplified yet improved standards for the manufactured products.

As a result of new methods for marketing fish, both fresh and preserved. new sources of fishery wastes are being created. Use of these materials in the manufacture of fish meal has caused a great expansion in this phase of fishery by-products utilization, and raw material is now obtained from four general sources: (1) Fish waste accumulated in the preparation of firesh packaged fish, salted fish, and smoked fish for market: (2) waste accumulated from fish-canning operations; (3) the portion of the catch of certain edible fish legally permitted for reduction; and (4) nonedible fish of inferior market value.

The above sources of raw material represent two general types of fish which may be classified according to their fatness. These are (i) fish which store their oil in the liver and have very little body oil, and (2) fish which store sufficient oil in the body to warrant recovery. Each type of raw material offers different problems of reduction, and the resultant products represent two types of fish meal according to oil content.

The meal from the type of fish which store their oil in the liver is known as white fish meal, and it is manufactured by at least three different processen. Thus we have racumm-dried white fish meal which has been cooked and dried in one operation, also rac- umm-dried and flame-dried white fish meals which have been precooked and pressed before being dried. The meals from the fish which store their oil in the body are known according to the species of fish from which they are manufactured. These are menhaden, sardine, herring, pilchard, tuna, and salmon. The general procedure for reducing this type of fish or the waste from them consists of (1) precooking to break down the oil cells; (2) pressing to extract the freed oil and moisture; and (3) rrying to remove the remaining moisture to a point where the meal will not spoil in storage. The cooking and pressing operations are more or less standard, but numerous methods of drying are used.

Recent studies by the Burean of Fisheries indicate that the feeding value of fish meals is determined more by the method of drying than by the species of fish. For example, there is more difference between the feeding value of flame-dried and steam-dried meal of the same species than between the flame-dried or steam-dried meal from two different species. These studies also show that the meals dried at low temperatures have greater nutritional value than those dried at high temperatures.

Further sturlies by the bureau also disclose that drying at low temperatures is actually more economical than drying at high temperatures, since there is a saving of material, which more than compensates for any additional cost entailed in low-temperature drying. Acceptance and application of this information should lead to the adoption of standard methods for the production and classification of fish meals, and for determining their quality.

\section{STANDARDIZATION BRIEFS}

A revision of the 1928 report on "Proposed Standard Tests of Broadcast Radio Receivers," recently published in the Proceedings of the Institute of Rarlio Engineers, is now a vailable from the Committee on Standardization. Institute of Radio Engineer's. 3:3 West Thirty-ninth Street, New York.

A number of new standards on generators, motors, and switch gear were approved by the standards committee of the National Electrical Manufacturers' Association, at its recent meeting held in New York. 'These rules and revisions will be published in the near future. Some of the standards approved are: Engine-driven alternators, planer-type motor's, elevator motors, motor generators, drip proof and fully protected motors, crane motors, oil circuit-breakers, switching equipment, transformers impedance, and attachment plugs.

The National Bureau of Standards has completed a determination of the wave lengths of the stronger lines in the first spectra of krypten and xenon to serve as additional standards of wave length for use in spectro- scopy and metrology. The wave lengths were compared with neon standards previously measured relative to the primary standard, the a verage probable error in relative value of the new standards does not exceed 1 part in $20,000,000$

The American Society of Mechanical Engineers annonnces that a proposed American standard for pipe plugrs of cast iron, malleable iron. cast steel of forged steel is being distributed in tentative form to industry for criticism and comment. Two other proposals, one for machine pins of both taper and eylindrical designs. and the other for steel base fittings, have likewise been distributed.

The sum of $\$ 100,000,000$ is spent annually on research laboratories of American industry, according to a snrvey made by the Standard American Corporation. Industrial research work done by more than 600 concerns takes $\$ 75,000,000$, the rest being spent by associations and bureaus. The corporation expresses the belief that the appropriation for the work will be still greater in 1931 . 
A standard laboratory method for testing the fastness of dyed wool to fulling is being worked out by the National Bureau of Standards in cooperation with the American Association of Textile Chemists and Colorists.

A new revision of a former report on standards for graphical symbols used for electric power and wiring, No. $17 \mathrm{~g} 2$, is now arailable through the secretary of the American Institute of Electrical Engineers, 33 West Thirty-ninth Street, New Tork.

State weights and measures conferences were held recently in New York and New Jersey. A representative of the National Bureau of Standards presented the results of a bureau study on the drainage characteristics of various types of lubricating-oil bottles, such as are used at filling stations for servicing automobiles. The results of the study are of importance in connection with a code of specification for such bottles, amended by the National Conference on Weights and Measures held last June in Washington.

The American Brush Mamufacturers Association. in cooperation with the National Bureau of Standards. has completed a survey to determine the rariations in size of Dutch. semi-Dutch, and baby Dutch kalsomine brushes. A summary of the data has been referred to the industry for the purpose of determining a basis for a simplified-practice recommendation covering this commodity.

As an outgrowth of the recently completer project on the simplification of abrasive grain sizes, the abrasive producing industry has appointed a research associate at the National Bureau of Standards to study sieves and sieving practices as applied to abrasives. and to prepare master grain samples. The research associate began his work October 1, 1930.

The printed booklet on Elastic Shoa Goring, known as simplified-practice recommendation No. 112-29, is now available for purchase through the Superintendent of Documents, Govermment Printing Office, IVashington. D. C., at a cost of 5 cents each. This recommendation has been instrumental in reducing the number of stock varieties of unmercerizerl corded cotton elastic shoe goring from 70 to 29.

The revised simplified-practice recommendation No. 61, Clay 'Tiles for Floors and $W^{\prime}$ alls (formerly White Glazed Tile and Tnglazed Ceramic Mosaic) has received sufficient signed acceptances from manufacturers, distributors, and users to insure the goneral atoption of the program by the industry. and is to ba considered as in effect from October $15,1930$.

How the Radio Mas Made Aerial Navigation Safel is the subject of a paper by Ethmond $\mathrm{T}$. Allen, test pilot and research engineer of the Boeme Airplane
Co., in the September issue of Mrchanical Engineering. In his paper the author tells about directive radiobeacons by means of which the pilot may keep accurately on his comrse regardless of visibility, about the radio conpass, and about radio triangulation for determining geometrically the exact location of an airplane on a map. He also reviews the broadcasting of weather information and how it helps pilots to know what to expect in the way of weather conditions on their flights, and how 2 -way voice communications make it possible for pilot and dispatcher to keep in touch with each other at all times.

The electrical-instrument section of the National Bureau of Standards is in process of erecting a new laboratory for testing current transformers of high range. Although installation of the equipment is not yet complete, tests have been made at currents up) to 6.000 amperes. These transformers are used as standirds by electric power companies in testing the meter's used in billing large power consumers.

Standard methods for the determination of levulose in sluar mixtures is the subject of an investigation approaching completion in the National Bureau of Standards. Levulose obtainable in limited quantities in a pure state occurs in wide distribntion in honer. sirups, and many plant products. For analysis of such products polarimetric, densimetric, refractometric, and chemical methods are used. For analysis of complex proclucts, it is sometimes necessary to use combinations of these methods. In order that these phvsical and chemical methods may be used reliably. the properties of the highty purified sugar have been determined with the necessary precision.

For the development of nondestructive methods of testing materials by magnetic analysis, it is necessary to obtain a large amount of fundamental data on the relationships between the structure and mechanical properties of materials and the magnetic laboratory, in seeking to add to the knowledge of these fundamental relationships, by investigations of the effect on magnetic properties of varions factors known to influence structure and mechanical properties.

The National Bureau of Standards is cooperating with the American Society for 'Testing Materials in the development of standaid methods for testing masnetic materials at very low values of magnetization. Materials which are manetically superior at moderately high values of magnetization ale not necessalily better at the low values commonly used in radio apparatus. It is necessiry, therefore, for purposes of specification and testing to have testing method. capable of vielding a satisfactory degree of accuracy at vely low magnetizations.

An investigation of the wind pressure on chimneys and other cylindrical structures has been in progress at the National Bureau of Standarels. The investiontion showed that the wind plessure is a function of the ratio of the hoinht of the chimmey to its diameter and 
that a wind pressure corresponding to 20 pounds per square foot of projected area at a wind speed of 100 miles per hour is a safe value to use in designing chinneys of which the exposed height does not exceed 10 times the diameter.

The magnetic laboratory of the National Bureau of Standards is studying methods for the standardization of apparatus designed for the measurement of the magnetic properties of materials under the influence of intense fields. This work has been made necessary by the development and increasing use of magnet steels containing relatively large percentages of cobalt and which are much superior to the older types of magnetic steel. On account of their low magnetic permeability, relatively intense fields must be employed for their magnetization.

The popularity of sound pictures as entertainment has created a new interest in auditorium acoustics. Even the layman has become conscious of the disturbing factors which natural or reproduced sounds may cause in a large room. The sound section of the $\mathrm{Na}$ tional Bureau of Standards has made, in the past several years, a study of various methods of measuring sound absorption. It has also initiated a cooperative program with the various manufacturers of acoustical materials for the purpose of measuring the sound absorption. It has also initiated a cooperative program with the various manufacturers of acoustical materials for the purpose of measuring the sound absorption coefficients of these materials. In many cases a $\mathrm{Na}$ tional Bureau of Standards report is required on acoustical materials to be used in public buildings.

Use of short-wave radio in maintaining communication between the ends of freight trains, which sometimes are more than a mile in length, has been found practicable, the Federal Radio Commission has been notified by the American Railway Association.

Experiments are being conducted at the National Bureau of Standards on the maintenance of constant vibrations of a free pendulum and the procuring of seconds signals therefrom. A photo-electric method of procuring the signals from the vibrations of the pendulum itself is used. These signals also cause an electric impulse to be given to the pendulum at definite intervals, thus maintaining its motion.

A general conference of all interests was held October 23, 1930, in Cleveland, Ohio, for the purpose of considering a proposed simplified recommendation covering glass containers for cottage cheese and sour cream.

At the plenary session of the Danish Committee on Standardization, held in May of this year, seven proposals for adoption as "Danish standards" were submitted. Among these which were thus adopted are: $52 \mathrm{~mm}$ fire hose coupling; thread for $52 \mathrm{~mm}$ fire hose coupling; Whitworth pipe thread $1 / 8$ inch to 6 inches; Whitworth fine thread $\frac{7}{32}$ inch to 3 inches, outside run off of thread and clearance of thread with rounding under the screw head, inside r'un off of thread and clearance of thread, and finally, casement mountings (angle hinges and iron corner braces). When the new DS-sheets are printed, 36 Danish standard sheets will be published.

Salesmen preparing to go out on their fall trips are much encouraged by the r'eports they are receiving of depleted stocks of merchandise, states W. G. Adams, managing director of the National Council of Traveling Salesmen's Association. It should be remembered that when placing new orders it is well for the merchants to stock the "simplified lines."

The elaboration of exact methods of sugar analysis has resulted in the discovery at the National Bureau of Standards of three new sugars occurring in dahlia tubers. 'Their discovery contributes to our' knowledoe of carbohydrate chemistry and to the nature of the starchlike substances occurring in certain plants. The same sugars occur in goldenrod, dandelions, chicory, and Jerusalem artichokes.

Slow thawing out of frozen inventories of merchants and manufacturers is noted by Prof. William L. Nunn, Department of Economics of the New York Eniversity, as the most favorable sign in the business skies. The stocking of standard "lines" is a most efficient way of preventing "frozen" inventories.

Twenty-four different brands of bed sheets have been in service in Westchester County, N. Y., public institutions for the past 17 months in tests to establish standards of durability. Samples of the sheets are now being examined in the textile section of the $\mathrm{Na}$ tional Bureau of Standards. It is expected these tests will be continued for two more years. The Cotton Textile Institution, associates for Government service, and the organization are cooperating in this work.

'The commercial attaché at the American Embassy, 'Tokyo, Japan, has advised the Department of Commerce that a committee appointed by the Japanese Government to study the rationalization of industry has translated into the Japanese language the first edition of the National Bureau of Standards' publication, Simplified Practice, What It Is and What It Offers.

In connection with the development of a commercial standard for waterproofed cotton duck for tents and tarpaulins, the textile section of the National Bureau of Standards is making a study of standard methods for testing such fabrics. Modifications of the "box" test and the "hydrostatic pressure" test are under consideration. 


\title{
INTERLINGUAL PUBLIC ADDRESS SYSTEM
}

\author{
Translation Into Several Languages Through Aid of Earphones Creates Greater Interest and Saves \\ Enormous Time in Presentation of Addresses
}

An interesting and important telephone multilanguage system has been developed for translating addresses for audiences at an international congress. This system was installed at the United States Chamber of Commerce, WVashington, D. C., for use in connection with the International Roads Congress.

The program of the congress called for two parallel sessions in different ascembly rooms. Two complete telephone systems were therefore necessary.

Microphones were provided for the presiding officer, the official recorder, and the speaker; and, in addition, a separate microphone was provided for each of the three translators, one translating from English into French and vice versa, one from English into German and vice versa, and the third from English into Spanish and rice versa, employed to take care of the necessary translation to and from the four languages officially recognized.

If the speaker employed the English language, his speech was directly received by each transhator, and each rendered it into French, German, or Spanish, respectively, by means of his individual microphone. The rendition into each of the languages was amplified and the amplified telephone currents distributed to a group of head receivers wired to circuits run to the back of the seats. Single ear receivers were used. The assembly hall was divided into sections. Each section was devoted to one of the four languages. These sections were reserved, respectively, for those preferring a particular language. The original in Enolish was received directly by ear.

If the language of the speaker was not English, it could be received direct and, in addition, the translator most familiar with the particular foreign language rendered it into English, in which form it was transmitted to the headphones of the English section and also to the other two translators, who rendered it into their respective languages.

The wiring and head receivers are so attached to the backs of the seats in each section as to eliminate the annoyance arising from interruptions from late comers passing to seats not on the aisle and thus having to pass seats already occupied.

Three or four stages of amplification were employed in order to make up for the relatively low efficiency of the microphones and to provide adequate current for the groups of head receivers.
An electrically recording phonograph was also provided for obtaining a faithful record of the words of each speaker just as they were giren; an attendant switching the microphone in use on to the recording apparatus. 'The recording cylinder were sent, as soon as completed, to the secretariat for exact transcription in the original language and exact translation into each of the languages recognized as official.

The transmission at the head receivers in the United States Chamber of Commerce auditorium was of ample loudness, thus requiring no further modulation, and of very clear articulation, thus meeting all essential requirements for satisfactory reception.

Another multilanguage system has been so designed that the translation into any language or the original speech itself could be listened to at any seat in the auditorium. In this case, it was necessary to run a group of wires, at least one more than the number of languages employed, to each seat, and to provide a multicontact switch for each listener by means of which he might select the language preferred. Double ear receivers are used. This system was employed in connection with the recent Berlin International Power Congress.

This system possesses the added advantage of permitting the number of head receivers to be kept to a minimum. In the aforementioned system, advance knowledge of the exact number of head receivers is required so that provision may be made for each of the language groups. At Berlin, a plug-in jack for connecting the head receivers was used, and the switches were mounted on the backs of the seats in front of the delegates, thus causing temporaly interruptions on the arrival of late comers. In addition, a switch for adjusting the loudness of the received speech was provided.

It is believed that all future international congresses, where more than one language will be employed, will avail themselves of some form of multilanguage system incorporating the essential features of those for the Berlin and the Washington congresses on account of the enormous saving of time in the presentation of addresses, papers, etc., and in the maintenance of greater interest in the proceedings on the part of the members and delegates.

\section{FROGS USED TO TEST STANDARD DRUG POTENCY}

Into the line between man and deatl are thrown 12,000 frogs a year, for the purpose of testing digitalis (the leaf of the common foxglove and greatest of heart stimulants). One of the most difficult drugs to standardize, the administration of digitalis used to be risky guesswork. Now the effect of each lot is ascertained by injecting samples of it into frogs, cold- blooded animals being used because of the independent action of their hearts.

'To determine the lethal effect of each sample, a frog must die. Digitalis makes the heart beat strong, but slowly allowing the heart to recuperate between beats. If a pulse rate of 120 a minute is reduced to 100 , the heart is sared 28,800 beats a day, and the total period of heart rest between beats is increased by four hours. Awaiting their turns, the frogs are sprayed with. water behind a glass door at $20^{\circ} \mathrm{C}$. (From September, 1930, Fortune.) 


\title{
BENEFITS FROM SIMPLIFYING VARIETIES IN SOFTWOOD LUMBER
}

\author{
Steady Increase Noted in Demand for Standard Items Eliminates Mistakes in Shipping
}

By James F. MCNeIL. National Bureau of Standards

The manufacture of lumber was one of the earliest. if not the first industry, to be started in this country. The colonists were obliged to erect cabins for shelter and stockades for protection against onslaughts of native marauders. It was also necessary for them to fell timber before they could cultivate the land. Spars, masts, and other ship timbers were exported even before many of the early agricultural products.

During the era of colonization and on through the formative stage of the Union. the manufacture of lumber was comparatively simple. Trees were felled als needed. sawed and hewn by land into rough logs and boards. Sawmills began to make their appearance in the year 1625 when one was erected in Virginia. These mills, howerer, were an unimportant factor until the advent of steam. early in the nineteentl century.

As the industry grew, not unlike many other industries, it became hampered by the accumulation of an enormous number of sizes, grades, and classifications which varied with each producing locality. This diversification was corrected locally by regional associations which drafted rules governing manufacture within specific areas. While the work of these associations in this respect was commendable and of much use in its limited sphere, nationally the conflict of the sizes. grades. and classifications became more and more rexatious, mainly because of the disadrantages encountered in using lumber which was manufactured in various sections of the country.

The present national lumber standardization movement had its inception at the first American Lumber Congress, held in April. 1919. where a resolution was passer faroring the unification of sizes of all softrood lumber. In June of that year, and in September, 1920, other meetings of representatives of the industry were held and much discussion was had on the subject of standard sizes, grades, forms, and nomenclature. Plans for future work were also outlined.

In May, 1922, 110 representatives of organizations of all interests met in general conference at Washington. D. C., inder the auspices of the dirision of simplified practice of the National Bureau of Standards. The principal action of this meeting was the appointment of subcommittees whose duty it was to formulate the necessary standards in sizes and grades and the mods of interpreting, applying, and enforcing them.

A second general conference was held in Chicago Ill.. in July, 1922. Here the Central Committee on Lumber Standards was ereated, its membership being composed of representatives of lumber manufacturers" wholesalers', and retailer's associations, the railway associations, the American Institute of Architects, and the Association of Wood Using Industries. A consulting committee to handle the technical phases of lumber standardization was in turn formed by the central committee.

The third general conference, in December, 1923. received the report of the central committee, and the meeting resulted in the approval of a simplification and standardization program which was instrunental in reducing the actual finished yard lumber items approximately 60 per cent.

In accordance with the usual procedure of the National Bureau of Standards, simplified-practice recommendations are subjected to review periodically, either by the standing committee of the industry or by subsequent general conferences. This procedure tends to sustain continued interest and adherence to the program and to keep it abreast with current practice. Four such general conferences have been held since the original simplification program on lumber was approved and accepted, the last taking place on May 3 , 1928.

The work of the committee at this conference marked the completion of their original plan concerning the simplification and standardization of softwood lumber. It now remains to keep these recommendations current by means of the aforesaid procedure of the bureau.

Simpified Practice Recommendation No. R16Lumber (fourth edition) includes recommendations for recognized classifications, nomenclature, basic grades, seasoning standards, sizes, uniform workings, description, measurement, tally, tally cards, shipping provisions, grade marking, and inspection.

\section{Eighty per cent adherence.}

At the time of the last conference it was estimated by the industry that 80 per cent of the softwood lumber in the United States was being manufactured in accordance with the American Lumber Standards. In 1925 it was estimated by responsible members of the industry that the waste eliminated by this simplification and standardization program exceeded $\$ 200,000$,000 per year.

To ascertain the practical effect of the application of these recommendations letters of inquiry recently were addressed to all acceptors and to several hundred mills located in all parts of the country. The following are excerpts from the replies:

"We have made an appreciable saving through grade marking our stock." wrote one mid-western manufacturer, "and this has saved us somewhere between $\$ 4,000$ and $\$ 5,000$ per year on claims."

Another manufacturer in the same locality said: "It increases the productive capacity of employees and machines and reduces warehousing and storage space requirements."

The sales manager of a mill on the west coast replied: "As American Lumber Standards, as provided in (Simplified Practice Recommendation) R16-29. have effected economies both to the manufacturer and to the distributor. without working any hardship on the consumer, it is highly logical to assume that they will soon be accepted 100 per cent. This has shown a saving to us perhaps of $\$ 4,000$ in our operations last year."

"We note a steady increase in the demand for standard items, which enables us to reduce onr manufactur- 
ing costs. inventories, etc.. considerably." stated the general manawer of another plant.

"Our saring has been chiefly in decreasing the anount of clegrade formerly secured on account of stock being too thin to dress to the former standard thickness, and also the increased underweights resulting from the thinner net thickness." said another manufacturer. He further states: "Mre would estimate such savings as being about $\$ 5.000$ per year. We might add that all such saving has been passed on to the consumer in the way of lower prices.

Is to the benefits which accrue to consumers, the secretary of a water users' association replied: "TV e have found that standard grading rules make for more uniform lumber: standard nomenclature avoids mistakes in ordering and shipping; simplified practice gives the buyer knowledge of what he can expect to find in stock for immediate shipment: it tends to lower prices by requiring a smaller amount of equipment to manufacture and by having to stock fewer sizes. We are engaged in cataloguing all of the material which we use, and simplified-practice recommendations certainly simplify cataloguing."
A roof contractor engaged in business in the city of New Iork wrote: "We derived the following benefits: Better value for the money and a greater protection against unserupulous traders."

A nember of a firm of engineers and architects said: "We believe that this work has been of definite benefit throngh reduction in cost of materials and greater speed in deliveries."

The interest shown in the foregoing replies indicates that much benefit, tangible in its nature, is being derived alike by the manufacturer, distributor, and consumer.

Briefly, it is claimed by members of the industry that the application of this simplified practice recommendation is resulting in a reduction of manufacturing costs and in inventories, and that less warehousing and storage space is required. Also that it makes for more uniform lumber, which minimizes the number of errors made in ordering and shipping. Deliveries are also expedited. All of which leads to more satisfactory business relations and to a greater stability of the industry.

\title{
HOME-OWNERSHIP DRIVE
}

\author{
Estimated $\$ 50,000,000,000$ Will Be Spent on New Residential Construction in Next 20 Years
}

'The President's Conference on Home Building and Home Ownership was called, according to the President, "to undertake the organization of an adequate investigation and study on a nation-wide scale of the problems presented in home ownership and home building, with a view to the development of a better understanding of the questions involved and the hope of inspiring better olganization and the removal of influences which seriously limit the spread of home ownership, both town and country."

Secretary of Commerce R. P. Limont, who is also chairman of the conference, in discussing a recent meeting of the planning committee stated:

Although months of committee wo:k w:ll precelle the main conference, and although it will deal, in large measure, with the long view of things, we believe that as the work derelops if will help in solving the inmesliate problems of the home building industry, and of tamilies that are trying to improve their homes. 'Through the press, and througl such organizafions as Better Homes in America, with its 7,000 local committees, important findings can be relayed quickly to the general public.

Estimates uresented to the very recent meeting of the Planning Committee in the Commelce Department indicated that at least $\$ 50,000,000,000$ will be spent on new residential construcfion in this country during the next 20 years, and that in addition upwards of $\$ 500,000,000$ a rear is being spent currently on lousehold repairs and maintenance.

A comparison of the most recent vacancy survess mad throughout the country indicates that in many centers the mumber of desirable vacant houses and apartments is not excessive, and that, with the present low rate of residential building activity, a resmmption of nole active building will soon be required by the needs of our steadily growing population and the razing of old structures.

\section{Conditions favorable for building.}

Also it was brought ont at the meeting that with recent drops in prices of important building materials, an ample number of highly skilled building-trades workers available, contractors anxious to obtain work, and first-mortgage money generally available at reasonable terms, conditions arc now favorable for home builders who have the resources and intend to build to go ahead. In general, conditions are also sood for going alead with repairs. alterations, and inprovements to existing houses.

The intense intelest shomn by all present at the meeting of the planning committee gires the best possible assurance of practical results from the rork. Representatives of organizations embracing millions of families in their membership soon found grounds of common understanding rith leading business. professional, and civic groups. The scope of work of the conference was interpreted broadly to extend over a vide range of problems connected with home making, family finncing, and housekeeping, as well as the provision and financing of new homes. Home financing came up again and again as an outstanding problem that had a bearing on numerous other questions.

Home building was interpreted to include not only the construction of houses, but the layout of subdivisions and the relationships hetreen home neighborhoods, the location of business and industrial centel's and the whole ploblem of industrial decentralization.

Anmple opportunities were developed for cooperation of a wide variety of groups whose interests touch upon the home and which will be invited, as the work goes on, to talie part in the work of the conference. It appealed that many existing constructive movements should be greatly strelugthened by gaining support from other groups during the course of the work. It was clearly brought out. for example, that assured quality of new construction, so important to home huyers and home builders, is a gonl that interests financing agencies who want the best possible serurities belinil their loans.

Reputable buildels want assurel quality hecause they suffer when an unserupulous or isnorant competitor puts impouerly built laouses on the markets, or bases a low bid on the expectiation of doing inferior work. It appears that there is a fruilful field for joint efforts on the part of lenders, builder's, alloitects, real estate men, matrial manufacturers and dealers, and several ofher groups in solving this problent.

\section{Urges use of best practice.}

Another point emplatsized at the meetine, was the progress that would be achievol if the hest practices in every branch of the honle-building industry could be asd generally. In the eace of subdividing new residential neighborloods, tor exinpls 
it appears that obsolete customs are often followed, whether bccause of failure of the home-buying public to realize the advantages of the best modern practice, lack of interest on the part of the subdivider, or the deterrent effect of obsolete laws or regulations that were not framed in the light of present-day conditions or knowledge.

The work of mapping out subjects for the different committees is going forward actively under the direction and advice of the planning committee of the conference, of which Dr. John M. Gries is executive secrctary. Although the work of the conference has had an auspicious start, we can not expect to accomplish miracles, but we do hope that every American family may be better off because of it.

\section{Department of Commerce aids better-homes move-} ment.

Dr. Julius Klein, in a recent radio talk, discussed the activities of the planning committee and described some of the advantages accruing to the individual home owner through the Department of Commerce. He spoke particularly of the services available through the National Bureau of Standards and its division of building and housing, and named some of the publications issued by the bureau, such as How to Own Your Home and Present Home Financing Methods.
Care and Repair of the House, another publication mentioned by Doctor Klein, will be issued within a few months. It deals with the maintenance of the structure and its equipment. He also mentioned a "Iist of published material relating to home building and maintenance," recently compiled in the National Bureau of Standards, which designates many publications that are available to home owners.

"In the whole problem of home ownership," Doctor Klein declared, "the question of municipal zoning is one that indisputably looms large. A home buyer often faces the possibility that the vacant lot next to his home may be taken over for some purpose that may spoil the house as a place in which to live, and force the family to sell out, with a loss that represents the slowly garnered fruits of frugality and selfdenial. Sensible zoning is the remedy for that and it is spreading space." The Advisory Committee on City Planning and Zoning is actively engaged in assisting municipalities in solving their zoning problems. Other committees are working to better building and plumbing codes.

\section{CERTIFICATION PLAN TO BE APPLIED TO BRICKS}

Effective cooperation in the application of the certification plan to Federal specification No. 504 for common clay brick has been received from the Common Brick Manufacturers Association, which has supplied the National Bureau of Standards with complete lists of clay brick manufacturers, both members and nonmembers, and is using "follow-up methods" to obtain 100 per cent representation of its own members on the bureau's list.

'The list of willing-to-certify manufacturers of common clay brick now contains the names of 325 firms. This number is 75 per cent larger than that of any other list of willing-to-certify manufacturers thus far distributed. Similar cooperation in the application of the certification plan to Federal specification No. 505 for common sand-lime brick is being given by the Sand-Lime Brick Association.

\section{INDORSEMENT OF QUALITY LABELS BY AMERICAN HOME ECONOMICS ASSOCIA- TION}

As the result of a request from the National Electrical Manufacturers Association, the American Standards Association is planning to make a study of the certification and labeling plans advocated by the National Bureau of Standards and other plans for making specifications effective. The American Home Economics Association has given official recognition to the proposed study by passing a resolution containing the following clause:

Resolved, That the members of the American Home Hconomics Association cooperate with the United States Bureaus of Home Economics and Standards and with the American Standards Association in an attempt to secure more labels for consumer's goods which will give accurate information to the orer-the-counter buycr.

\section{OFFICIAL TIME ZONE MAP OF THE UNITED STATES ISSUED BY BUREAU OF STAND- ARDS}

A map showing the standard time zone boundaries for the United States, with adjacent parts of Canada and Mexico, has just been issued by the National $\mathrm{Bu}$ reau of Standards. This is the first official map of its kind issued by the Federal Government. The base map was supplied by the United States Geological Survey and the time zone boundary lines placed upon it from information furnished by the Interstate Commerce Commission, the Hydrographic Office of the Navy Department, and the Dominion Observatory of Canada.

It will be useful in determining true and local time for radiobroadcasts, those making long-distance telephone calls will find it of service in keeping appointments, and it will be helpful to those planning trips by auto or rail. The aviator is particularly concerned in connection with transcontinental and other flights. It will be an asset to business, since the closing hours of offices are governed by local zone time and a complete knowledge of the zone boundaries and the territory included between them is desirable. Hotels, service stations, ticket offices, and places accommodating transients may find it a convenience to their patrons to have such a chart on display for consultation.

The map is printed in light blue on a white background, the locations of the cities being indicated in black lettering, and the time zone boundary lines appear in recl. Its dimensions are 20 by 30 inches. Copies of this chart, designated as Bureau of Standards Miscellaneous Publication No. 111, may be purchased from the Superintendent of Documents, Government Printing Office, Washington, D. C., at 10 cents each. 


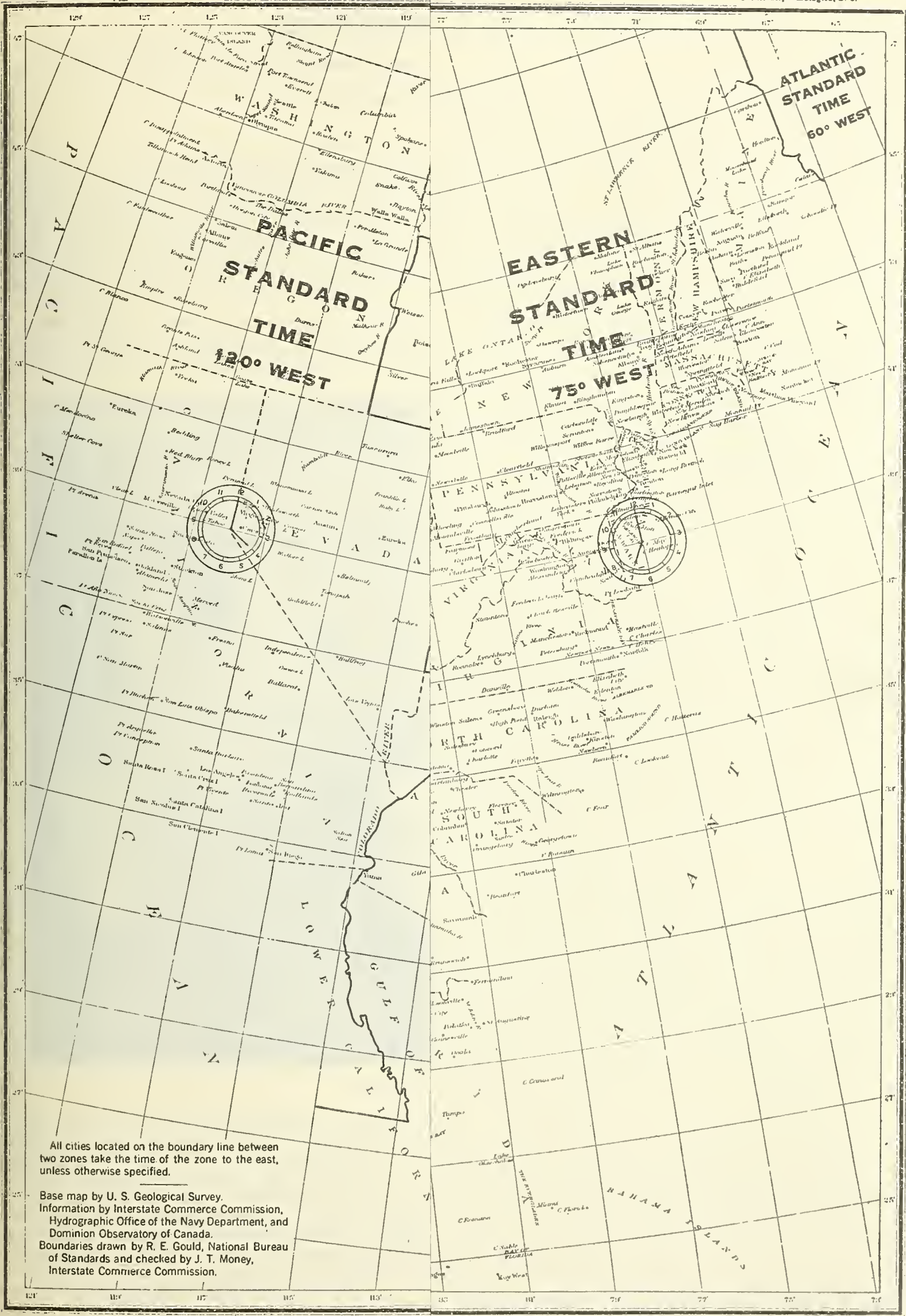


it appears that obsolete customs are often followed, whether because of failure of the home-buying public to realize the adrantaose of the best modern nractice. lack of interest on the
Care and Repair of the House, another publication mentioned by Doctor Klein, will be issued within a 


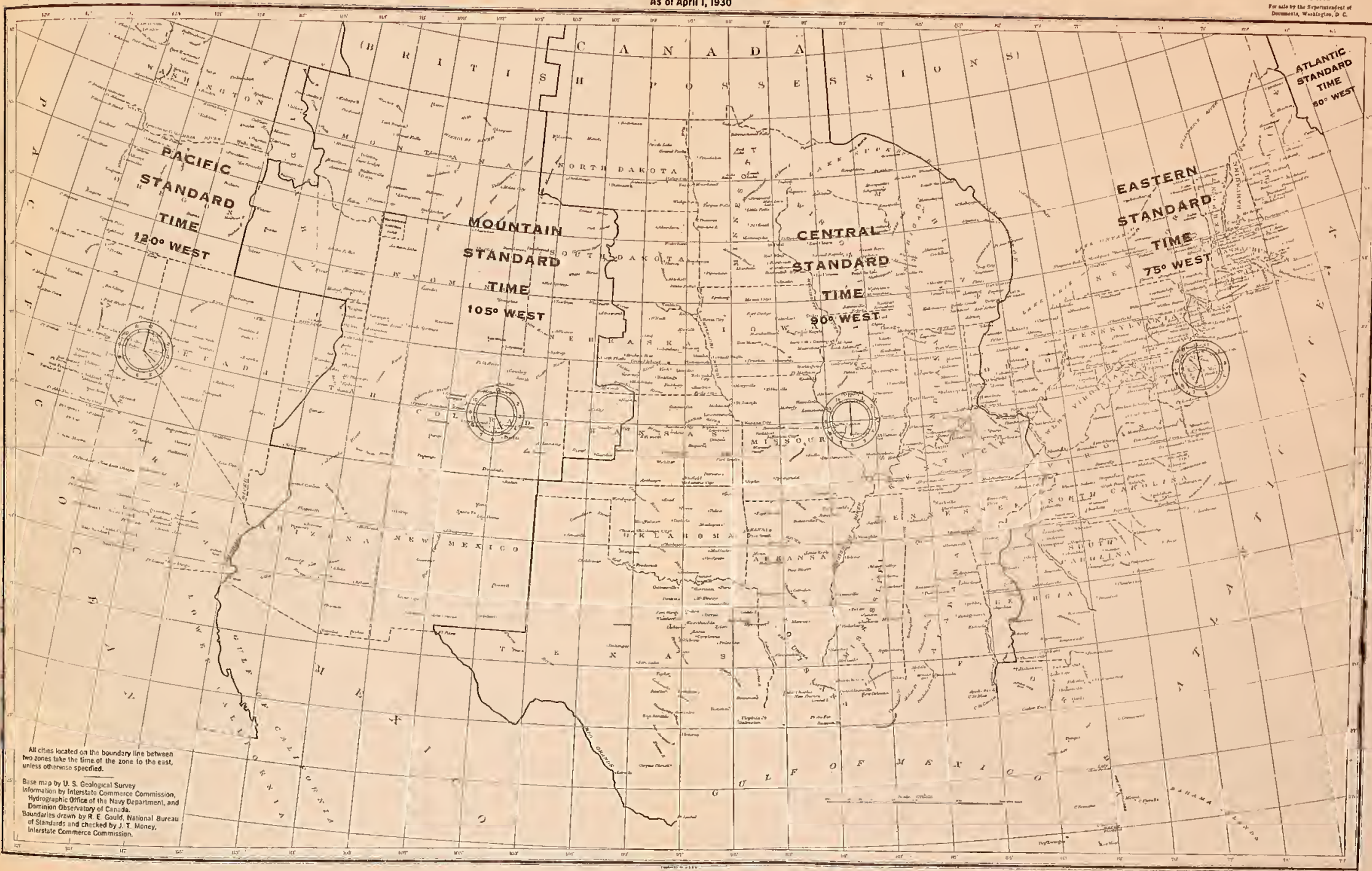





\section{BITUMINOUS MATERIALS TESTED}

Acce ed Weathering Tests Determine Durability of Bituminous Materials and Control of Manufacture

By O. G. Strieter, National Bureau of Standards

Exposure to actual weathering conditions has long been the common practice in testing the durability of structural materials. However, such tests are usually slow, frequently requiring a number of years, and in many cases are valueless because new sources of material and advanced methods of production have rendered the original material obsolete before the test leted.

s st that would duplicate the results of long periods of actual weathering in a comparatively short time is therefore extremely desirable. In developiner
The accelerated weathering machine consists of three lamps and three cylinders; each lamp and cylinder forming an individual unit. The bituminous materials for which the cycle was particularly developed, are surfaced to 0.025 inch thickness on aluminum panels. These prepared panels are then placed inside the cylinders and there exposed alternately to light and water. For refrigeration a separate unit is used.

\section{Results of tests.}

The relative rapidity with which results are obtained with the aid of the accelerated cycle is an important

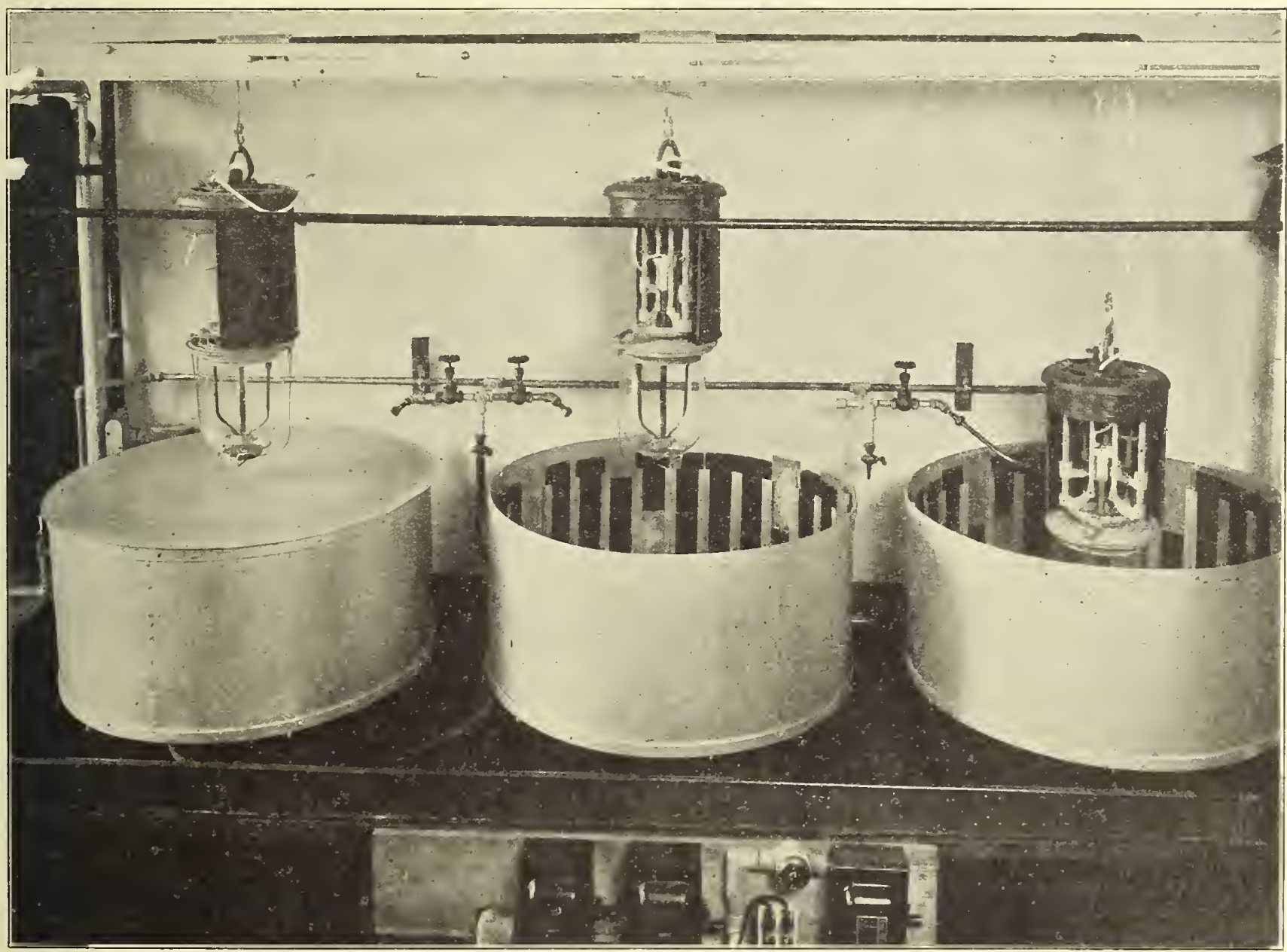

The accelerated weathoring machine

such a test at the National Bureau of Standards the most obvious course has been followed; that is, the important factors of outdoor weathering are reproduced in intensified form in the laboratory.

The laboratory test, as developed at the National Bureau of Standards, consists in subjecting the material to a cycle of alternate exposures to light from an inclosed carbon arc lamp (artificial sunlight); to water spray from a rotating lawn sprinkler (rain); and to refrigeration (temperature changes). feature. Indications as to the probable durability of a bituminous material are obtained after from 10 to 20 cycles of exposure in the accelerated weathering machine. The time required for the bituminous material to crack through to the aluminum panel indicates the durability of the material.

In the accompanying photograph are shown panels of various bituminous materials specially prepared to show differences in behavior. 'The panels in the upper low of the photograph were exposed ontdoors for one 
and one-half years. The duplicate samples in the lower row were exposed to the accelerated cycle for 70 days. By comparing a panel of the upper row. with the one immediately below, the remarkable similarity between outdoor exposure and accelerated weathering becomes evident.

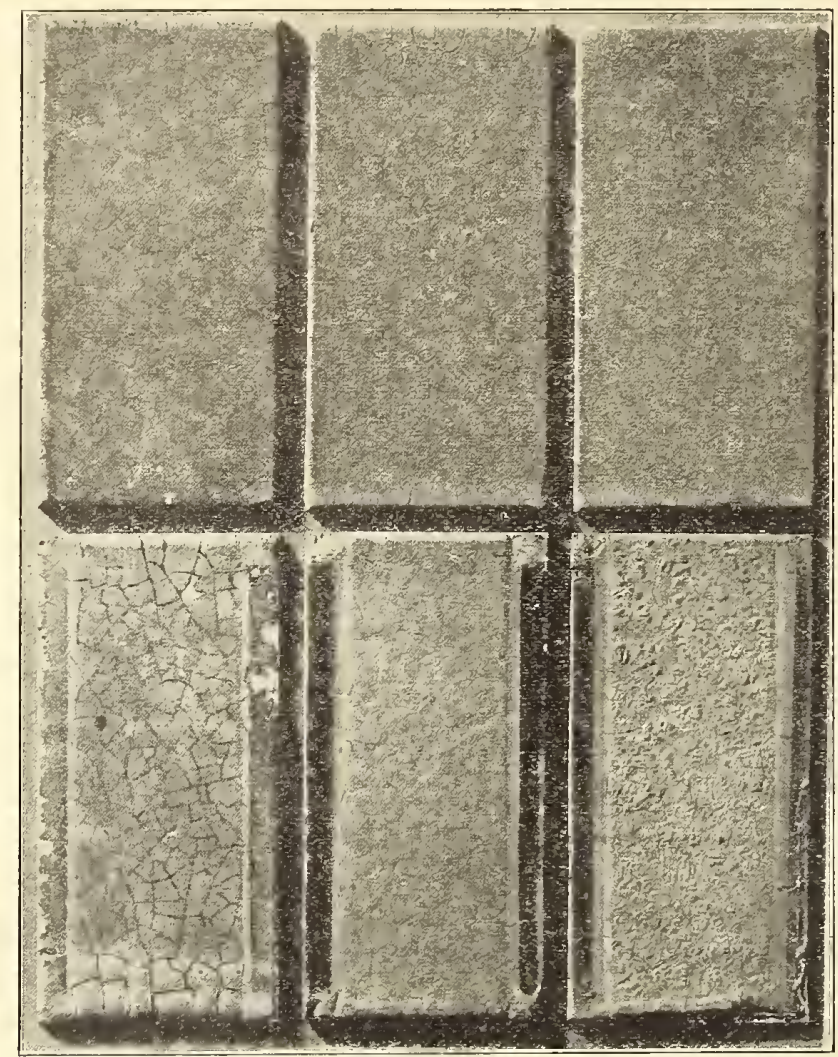

Upuer row shows outdoor exposures; lower, the accelerated ryele

Owing to the similarity of the two kinds of exposure, the accelerated test gires correct results in testing bituminous materials for durability. 'The test is valuable for controlling mannfacturing processes and for determining the durability of such materials.

Further details regarding the method may be found in the August, 1930, issue of the Bureau of STAxpards Journal of Researcir, or in the reprint. Research Paper No. 197.

\section{STANDARDIZING LITHOGRAPHIC PAPERS}

Joint Research Started by Lithographical Technical Foundation and National Bureau of Standards

Joint research by the Lithographic Technical Foundation and the National Bureau of Standards has been started for the purpose of standardizing lithographic papers. While the Lithographic Technical Foundation has made considerable progress in technical studies relating to lithographic printing, the bureau's assistance was requested in this branch of research as they lacked the facilities for the fundamental studies of paper qualities required.

Mechanical development in the lithographic printing industry has been rery rapid in recent years. One of the outstanding derelopments is the offset process which permits production of high-grade printing at greatly increased speeds. Lack of knowledge, howerer, of the characteristics required in papers to suit them to high-speed printing processes of this kind, has prevented full realization of the economies made possible by them. Some of the difficulties, which cause losses in both production and materials, are misregister of printing due to distortion of paper, nonuniformity of ink reception by the paper, and deterioration of printing plates caused by chemically or physically active substances in the paper. While such difficulties are not always the fault of the paper, a thorough study of the relation of paper characteristics to the rarions printing operations should lead to a better understanding of the particular characteristics required in the papers to obtain optimum printing results.

A committee representative of the lithographic printers and manufacturers of lithographic printing supplies has been formed to assist in the work in an adrisory capacity.

\section{STANDARDIZATION OF PRINTING AND WRITING PAPERS}

Processing of the Fibers Important in Determining Rate of Deterioration of Paper

Through a review of the information available, including both laboratory studies and the history of the natural aging of papers, it has been found that the processing of the fibers and the care taken in the various paper-making operations are important factors in determining how well papers will withstand deterioration. The strength of paper and its purity are dependent on these factors.

Papers must have sufficient strength to withstancl the mechanical stresses incidental to their use and must have sufficient purity, both cellulosic and noncellulosic, to guard against chemical reactions that induce decomposition. The basic constituent of paper fibers is cellulose, which is one of the most permanent forms of known matter. Cellulose is very susceptible. however, to deterioration induced by impurities that may be associated with it and by some of the chemical: that are used in paper manufacture.

From these considerations a classification based primarily on strength and purity is suggested, which places printing and writing papers into four groups: (1) permanent papers, (2) papers having a minimum life of 100 years, (3) papers having a minimum life of 50 years, and (4) papers for temporary use.

It is suggested that the various grades for all, except the papers intended for temporary use, be defined by limits for alpha cellulose, copper number, rosin, and acidity, as all of these properties appear to have an important bearing on aging quality. A high content of alpha cellulose and a low copper number are considered the best known indications that the paper fiber's have the basic purity required for long life. Minimum amounts of rosin and acid are desirable as these componeuts are harmful to any fiber, no matter how pure it may be, if they are present in excessive amounts. 


\title{
THE GOVERNMENT LABORATORY AND INDUSTRY ${ }^{\prime}$
}

\author{
Growth of Research Laboratories a Noteworthy Achievement of Present Century; Physical Sciences \\ Dependent on Science of Measurement and Art of Observation
}

By George K. Bergess, Nirector, Nutional Burean of standards

"The world of to-day is ruled by physical science and by business, which, in the rast proportions industry and commerce have now attained, is itself the clitd of physical science."

This recomized dependence of our modern civilization on the adrances in physical science has been a gradual derelopment. extending orer a long term of vers, but with ever-accelerated growth during the jresent century.

As business is the child of physical science, the latter, in turn, has as its parents the science of measurement and the art of observation without which the physical sciences could not exist. It was just 50 years ago that 16 governments, including three Latin American countries, recognizing the need of unifying exact measurements and of establishing international standards, joined together and organized the International Burean of Weights and Measures in Paris. Thus came into being the first scientific laboratory organized to help commerce and industry by providing the basic units and standards of mass, length. and temperature. At the present time this laboratory, whose functions are being rapiclly expanded to include electrical, photometric, and other standards, is supported by 32 nations, including seven from Latin America.

Weights and measures departments have been in existence for many years in several countries.

However, it was not until 1887 that the first national physical laboratory was established by the German Government in order to provide facilities to help? industry by testing and experimental research in the field of the physical sciences. This action was followed in 1899 by Great Britain, and in 1901 by the United States and several other countries which have established similar national laboratories, although in some of these countries, as France and Japan, the functions are distributed among two or more physical laboratories.

\section{Growth of laboratories.}

It is an interesting fact, that the more highly dereloped industrial nations, as distinguished from the agricultural, did not realize the need for such national physical laboratories until about the beginning of this century, but where once established these laboratories have proven themselves of so great benefit to their respective countries that generous support on an everenlarging scale has in all cases been forthcoming.

Even greater progress has been made in certain industrial countries, especially in Germany and the United States, by the action of the industries themselres in establishing research laboratories, notably in chemical, metalluroical, and electrical fields.

Maurice Holland, of the National Research Council, 1 This article by Directol Burgess is based on the speech delivered by
him before the Hirst Inter-American Conference on $\Lambda$ griculture. Forestry, and Animal Industry, held September 9, 1930 , in Vishington, D. C. A second article will appear in the December issue of the Comarerial STAXD.Mids MoNTHLY. is anthority for the statement that "nearly threequarters of a million dollars is spent every working day in the United States to improve the manufactuxing processes, reduce production costs, and derelop new fields of application and by-products in the Nation's industries. An increase of from 500 industrial research laboratories in 1921 to more than 1.500 in 1930. a 200 per cent increase in nine vears, tells the story of this new economic trend."

The growth and multiplicity of these laboratories is one of the most noteworthy achievements of the present century ${ }^{2}$ adrancing as they do the economic position of the country, and contributing to the development of natural resources, cutting cost of production, improving the commodities produced. eliminating manufacturing wastes, and building up new inclustries.

Let us consider some of these Government laboratories in their relation to industry. In Great Britain there has been on trial, since 1918 , with varied success. a cooperative arrangement between Government and industry whereby an inclustry sets up a research association which establishes a laboratory, and the cost of the experimental work is shared by the state and by the industry, originally half by each. but now the Government pays not orer one-quarter of the expenses of an association. At present there are 24 of these research associations, toward the smpport of which the British Gorernment provides slightly more than $\$ 300.000$ a year.

The British Government maintains a single department of States in which are grouped all governmental research activities, other than those relating to national defense. This is known as the "Department of Scientific and Industrial Research," which, in addition to the National Physical Laboratory and research associations. maintains laboratories for research in chemistry, foods, forest products, fuel, radio, water pollution, and geology, with a total expenditure of about $\$ 3,300,000$ in 1929 .

It is the practice in several cointries, even of some of those having national institutions to use as a $111-$ cleus existing educational institutions and make governmental provision for physical, technical, or industrial research at those institutions. The Australian Gorermment, for example, uses this method extensively.

\section{Practice in Japan.}

Still another type of governmental inchstrial cooperation is practiced in the Tnited States and oapan whereby industrial groups maintain research associates working at the Government laboratory, as at the National Burean of Standards, where there are about 100 persons so engaged. At the Japanese Industrial Research Institute, a part of the Department of Com-

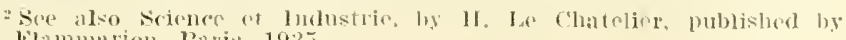
k. Nammariom, Paris, 1925. 
merce and Industry, there is a separate building known as the General Public Laboratory, where firms or individuals may rent laboratories for their work and also be aided by the official staff.

A very important function of some of the Government laboratories is the testing of supplies and equipment purchased by the Government to insure that the quality of the materials or the performance of the equipment submitted meet the requirements that have been defined in specifications, which again usually require for their formulation a great deal of preliminary experimental research work in laboratories. A large part of the resources of the National Bureau of Standards is devoted to such testing. Of particular interest is the Electrochemical Laboratory of the Ministry of Communications in Tokyo, to see how thoroughly the Japanese Government is carrying out this laboratory inspection of all purchases of electrical equipment. More than 1,000 men are engaged in testing electrical equipment and carrying on research in electrical phenomena, especially as related to power transmission, illumination, communications, standards, materials, and instruments.

Another field of activity engaged in by the Govern ment laboratory relates to the improvement or development of products or processes of national interest from the economic point of view. As an illustration, investigations under way at the Industrial Research Institute of the Japanese Government relate to a new chlorine process for sugar refining, utilization of fish oils in soap manufacture, improvement of Japanese clays for pottery, a study of water-resisting lacquered wares, synthesized dyestuffs, textile printings, new papers from mulberry bark, and new chemical products from marine animal oils.

A very remarkable institution known as the Institute of Physical and Chemical Research is conducted in Japan. A corporation was formed in 1917 with an endowment of about $\$ 3,250,000$, one-half of which was furnished by the Government. The expenses are met by income from investment and sale of patents, appropriations from the Government, and gifts from industry. The budget for 1930 is more than $\$ 700,000$. Quoting from official description: "The institute conducts investigations in the pure sciences of physics and chemistry, aiming at their industrial development, and at the same time engaging in applied research. No undertaking, whether it be in industry or in agriculture, would be able to attain somnd development unless it were based upon physics and chemistry." Here, indeed, is an emphatic indorsement from the Far East of James Bryce's statement of the world of to-day being ruled by physical science. At this Japanese institute there are 30 laboratories carrying on work on nearly 200 problems, with a staff of more than 500 persons.

It is well to remember that within the span of life of men still vigorous Japan has emerged from a feudal, mainly agricultural state, supporting for the previous century a stable population of 25,000,000, to a nation more and more intensely industrial, supporting in the same area a population of more than $63,000,000$, accompanied by a tremendous increase in national wealth. In terms of this wealth and population the Japanese Gorernment is probably spending more than any other on the development and application of the physical sciences through its governmental laboratories.

\section{Interest in European countries.}

Sevelal of the Eureopean countries which have achieved their complete independence since 1918, such as Finland, Poland, and Czechoslovakia, have recog. nized the advantages of governmental support of research in the physical sciences and have established or are actively organizing such laboratories, either as independent establishments or attached to an educational institution, or in direct association with national industries. In the East Indies the Netherlands maintains a testing and research laboratory on the Island of Java and the Philippine Government a Bureau of Science.

'The United States Government's interest in agriculture has grown at an ever-increasing rate since Benjamin Franklin sent silkworm eggs and mulberry cuttings from England. Washington, our first President, farored a central agricultural department which might draw "to a common center the results everywhere of individual skill and observation," and spread them "hence over the whole Nation." Also, President Taylor, in 1849, favored a Federal unit of agriculture with the words "to elevate the social condition of agriculturists, to increase his prosperity, and to extend his means of usefulness to his country by multiplying his sources of information, should be the study of every statesman and a primary object with every legislator." These words of 80 years ago are as pertinent to-day as when first uttered.

\section{Department of Agriculture established.}

The United States Department of Agriculture was finally established in 1862 and has had a phenomenal growth; its great laboratories and field stations have been a wonderful asset to the Nation.

The interpedence of agriculture and industry is in many cases very marked and there are also many examples of a manufactured commodity displacing an agricultural product. The classic example of the latter is the replacement of indigo from plants by a coal-tar product. 'This study of the possibility of developing staple products from new sources of supply or finding substitutes for existing products has become more and more an important function of Government laboratories. As an illustration of this type of activity may be mentioned the work of the National Bureau of Standards on sugars.

\section{Results achieved at National Bureau of Standards.}

Several years ago the National Bureau of Standards showed how to produce granulated dextrose econoically; a sugar now readily recovered from corn, and the resulting corn-sugar industry has already attained a firm position in the United States. We are now trying to solve the question, with prospects of ultimate success, of the economic production of the sweetest of the ordinary sugars, known as levulose, readily recoverable from a tuber, the Jerusalem artichoke, which can be grown anywhere in the United States. The bureau has also been investigating, in cooperation with industry, the production and utilization of an- 
other sugar, xylose, which may be recovered from sereral agricultural products, including corn, peanut sliells, and cotton hulls.

Another recent example of substitution is that of rayon displacing cotton to a serious extent, affecting not only agriculture but also the textile industry profoundly.

A natural product which has long fascinated the chemist is rubber. We have seen the gradual substitution of the cultivated for the wild plant and the study of the behavior and vield of new plants, such as guayule, and the chemist has even succeeded in producing synthetic rubber. At the bureau we have examined rubber said to have been extracted from crude petroleum, and within the past few months we have produced in the laboratory rubber in crystalline form. Where these discoveries will lead no one can say, but in the past history shows that with a glimmer of hope to light his way the physical scientist will not be turned aside from his goal.

\title{
THE “REICHSKURATORIUM FUER WIRTSCHAFTLICHKEIT” (RKW)
}

\author{
German Organization Receives Its Financial Support from the Government, But Is Rather Independent \\ in Its Function
}

By H. Hinnenthal, Governing Board of the RKW, Berlin, Germany

It is often inferred from the name of "Reichsliuratorium "that it is a Federal office. This is not the case. The designation "Reichs" has a twofold significance in Germany. In some cases it means an official organization or Federal office, such, for instance, as "Reichsministerium" or "Reichspost"; frequently, however, the prefix "Reich" signifies merely that an organization is meant whose sphere of activity extends over the whole empire, not only over one of the German States, like Prussia, Bavaria, Saxony, etc., such, for instance, as "Reichsverband Deutscher Industrie" as opposed to "Verband Saechsischer Industrieller," etc.

This means that the "Reichskuratorium fuer Wirtschaftlichkeit" (RKIV) is a national office for promoting rationalization in the whole of Germany. It is entirely independent in its activities and decisions and operates under its own administration. As it is not an official organization, it is not subordinate to any Government office, although it receives its financial means exclusively from the Government.

The RKIV consists of three parts: (1) The governing board (for the time being 20 members with a president, vice president, and secretary); (2) the finance committee (for the time being 15 members with a president and vice president); and (3) the general meeting (at present consisting of about 350 members).

The governing board is authorized to lay down the operating plan of the RKW and the decisions regarding the promotion of rationalization work to be performed outside the RKIV (committees, working groups, individuals). It is composed of business representatives. The supervision of financial matters and the employment of financial means lies with the finance committee which is chiefly formed by members of parliament and ministries. The general meeting elects the governing board and finance committee.

Just as the RKW carries the entire responsibility for its work and was purposely not made a dependent Government bureau, so the relations between the RKIV and the organizations whose work it lias to promote have been kept as free and independent as possible. These organizations are chiefly corporations and committees which have been formed either by the RKIV or other bodies. Their relations to the RKW are not of a subordinate but of a cooperative nature. They are independent corporations with their own administration. Only three committees which were appointed by the RKIV, and the expenses of which are borne almost exclusively by the RKW, form an exception in a certain sense, namely the "Ausschuss fuer Wirtschaftliche Fertigung" (Committee for Rational Manufacture); the "Ausschuss fuer Wirtschaftliche Verwaltung" (Committee for Rational Administration); and the "Reichsausschuss fuer Lieferbedingungen" (Federal Committee for Trade Practices).

\section{Outline of Procedure.}

Each of the above committees is entitled to apply to the RKIV for funds for the performance of rationalization work. The RKIV examines the applications with a view to the economic necessity and urgency of the operations suggested as well as to the possibility of their being carried through efficiently and promptly. It is entitled to grant financial support on condition that the operations be limited or extended. It has the right to give directions and orders for publication, as well as to determine the composition of the committees; it is in a position to prevent duplications, etc. The operation orders are, therefore, based on contracts and agreements made for the purpose of performing definite rationalization work from which the general public and German business would benefit.

The RKIV is entitled to supervise permanently the expenses which are only incurred in the executive offices of the committees (salaries, rent, heating, light), as well as for publication and printing, for travels, meetings, exhibitions, tests, etc., as the committees themselves only consist of honorary members.

The operations may be suggested either by the committees to the RKIV or by this latter body, which may transfer them to the committees. In its decisions the RKIV is chiefly guided by the consideration whether the operations suggested are of practical use or whether the rationalization work in question or preparatory work in this connection is desired by the Crerman industry. Mere research work. the practical value of which is uncertain, is excluded from its activities. The following examples will explain the operation of the three committees already referred to. 
Committee for Rational Manufacture receives financial support for laying down rules for making time studies in various industries, for publishing machine cards containing full particulars on all machine tools on hand in the factory, for rules for loading stations of electric trucks, for rules for packing material of wood, board, sheet metal, for packing for ocean transportation, ete.

Committee for Rational Administration concerns itself with drawing up uniform bookkeeping systems for certain trades, with laying down guiding standard figures for the retail trade, with budget control, with examinations as to the working capacity of office machines, with standard rules for filing systems, etc.

Federal Committee for Trade Practices issues agreements on delivery conditions and tests. " Delirery conditions" are limited to a certain group or interested parties stated by name, whereas "standards" presuppose universal validity. Delivery conditions have, for instance, been issued for leather, rubber, textiles, woodenware, paper, and colors.

German Bureau of Standards, formed about four years previous (1917) to the institution of the $\mathrm{RKW}$ (1921), is an organization independent from the RKW. It receives, however, substantial subsidies from the RKW for working out standards not serving individual but general requirements of the German industry and offering special advantages to consumers. The sums are subject to special agreements for each individual case. Special attention is paid to standards for household devices, hospital equipment, laboratory supplies, paper forms, etc.

Other conmittees concern themselves with rationalization work in agriculture, in connection with tests of law materials, technical education, small industries. household, etc. All principal committees have formed subcommittees for their operations, so that about 200 sub or trade committees with approximately 4.000 honorary members are affiliated with the RKIV.

Working for the general economic interests.

As the RKW receives its financial means exclusirely from the Government and, therefore, so to speak, from the whole Nation, it has the obligation to employ them only for purposes serving general economic interests. This is the essential condition for such operations promoted by the RKW as are jointly carried out by producers, merchants. and consumers. If these thrce groups come to an agreement. it may be assumed that general wishes have been complied with. It is therefore of the utmost importance that the aforementioned three groups be represented in the committees in equal proportions.

Although the RKW is not in a position to extend its activities to some lines, owing to the limitations imposed upon it by the source from which it draws its funds, yet the Gorernment subsidies are a guarantee for the neutral and objective character of its work. If the RKIV would only be maintained by the industry or only by the trade, it would be under obligations to them and would not be in a position to fulfill its task which lies in the promotion of cooperative work, in the removing of differences, and in the furtherance of business as a whole.

Through the medium of its financial and publication services, the RKIT is, so to speak, a clearing house between the committees and corporations engaged in rationalization on the one hand and trade and industry on the other. The subsidies granted to the RKIV by the Government are converted into practical rationalization work, the results of which are a collection of rationalization devices which are at everybody's dis. posal. That does not necessarily mean that the RKW recommends these devices always and to everybody. As it only has a limited staff of officials at its disposal, it is not in a position to acquaint itself with the full particulars of each individual case. The interested parties have to as ume the responsibility of choosing from the material offered such methods and devices as look promising. Decisions are made only after thorough investigation of all the possibilities.

The RKWV issues a monthly paper ("RKIT Nachrichten") in which are reported all rationalization questions and the activities of the RKIT. Furthernore, a series of pamphlets is published (in all, 60 pamphlets to date), giving particulars on each individual operation. A survey of the operations is given in the "Handbook of Rationalization." This handbook consists of three parts: Part 1, "Trend Toward Rationalization" (Germany and other" countries; part 2, "The Means of Rationalization" (standardization, manufacture. administration and distribution, special training. trade, and household): part 3. "Methods, Application, and Results" (tests made in factories, examples from actual experience).

\section{EXCELLENT ADHERENCE NOTED TO STAND- ARD ON REGAIN OF MERCERIZED COTTON YARNS}

As a result of a recent survey among the manufacturers to determine adherence to the Commercial Standard on Regain of Mercerized Cotton Yarns, a summarized report was issued on October 3. indicating that 100 per cent of present adjustments for regain of mercerized cotton yarns are on the commercial standard basis. Several manufacturers indicated that in general adjustments are not necessary, but that where adjustments are required they will use the commercial standard as a basis.

In accordance with recommendation of the standing committee, the existing standard was reaffirmed without change for another year beginning July 1 , 1930 .

\section{STANDARD FIRE-FIGHTING EQUIPMENT FOR METAL MINES APPROVED}

Fire-fighting equipment in metal mines has been approved as an American standard by the American Standards Association, according to an announcement of the American Mining Congress. The standard, sovering fire-fighting equipment, preventive measures, fire signals, and fire-fighting per'sonnel in metal mines, was dereloped by a committee of the American Mining Congress.

This standard. developed by a large and representative committee and now approved as an American standard, should be adopted and put into use in metal mines throughout the country as the best possible fire insurance obtainable, states the American Mining Congress announcement. 


\title{
FEDERAL SPECIFICATIONS PRINTED IN STANDARD FORM
}

\author{
To Broaden Field of Supply Many Firms Are Listed Under Certification Plan
}

Since Decenber 3, 1929, following the adoption of a new form and a revised procedure, the Federal Specifications Board has been formulating new specifications and revising old Federal specifications to include purchase details in addition to technical details. Also moler this new procedure, all Federal specifications will be printed in a standard form for the use of the entire Federal Government, and will bear standard symbols and nomenclature conforming to the Federal Standard Stock Catalogue.

In the past many of the departments have incorporated only the teclinical details of the Federal specifications in their own departmental specifications. Under the new procedure, with few exceptions, the departments will not reprint Federal specifications.

The Federal Specifications Board is also revising all provisions specifications to include classes and grades of food for the mandatory use of all departments and establishnents of the Federal Gorernment. Heretofore, the use of such specifications have been mandatory upon the Army, Navy, and Marine Corps only, and optional with the other branches of the Government.

'To assist in broadening the field of supply under Federal specifications, the National Bureau of Standards has compiled 271 lists of firms who have expresserl a desire to have their name placed on the willing-to-certify lists of manufacturers. Upon request, these producers are willing to certify that their products are in accordance with the designated Federal specifications. Information regarding the certification plan may be obtained from the National Bureau of Standards.

Copies of Federal specifications may be purchased from the Superintendent of Documents. Government Printing Office, Washington, D. C. Prices range from 5 to about 20 cents. If these copies are desired by Gorermment departments and establishments, they may be obtained through the representative member of the Federal Standard Stock Catalogue Board, or if there is no member representing an establishment. copies may be obtained through the chairman of the Federal Standard Stock Catalogue Board, Room 1149, Nayy Building, Washington. D. C.

Ferleral specifications, officially adopted by the Federal Specifications Board, will not be available in mineographed or printed form for gratuitous distribution.

\section{MCALLISTER, NEW ASSISTANT DIRECTOR OF BUREAU OF STANDARDS}

The appointment of Dr. Adrlams S. MeAllister. chief of the division of specifications, to be Assistant Director for Commercial Standardization of the National Bureau of Standards, was announced September 27,1930 . Doctor NeAllister will continue to act as chice of the division of specifications.

In 1921 he accepted the position of electrical engineer at the bureat, and soon thereafter was placed in charge of the specification work. Upon the organization of this work into a separate division in 1927. he was chosen as its chief. In the latter capacity he has come in contact with practically every technical and trade association in this conntry; with all State purchasing agents, and with many other National and State officials.

Before becoming associated with the National Bureau of Standards, Doctor McAllister was associate editor and later editor of the Electrical WVorld. He has served as manager and vice president of the American Institute of Electrical Engineers and as director and president of the Illuminating Eugineering Society.

\section{NEW CIRCULAR ON CLEANING MATERIALS}

\section{List of Government Specifications Included}

To answer many mail inquiries from the public, the National Bureau of Standards has prepared a circular on Washing, Cleaning, and Polishing Materials. This publication is an expansion of the bureau's Circular No. 62 on "Soap," issued January 24, 1923, and is designed to give information in a concise and popular" style.

The paper discusses the use of water in laundering, pointing ont the effects of impurities in water and means for their removal. A description of the general composition of soap, soap manufacturing processes, and the common varieties of soap products, is followed by brief discussions of alkaline cleansers (including drain or waste pipe cleaners), bleaches, laundry scours, bluing, and starch. Discussions are also included on dry cleaning, dry-cleaning solvents and soaps, stain removal, finishing of cleaned garments, reclamation of dry-cleaning solvent, and elimination of static electricity in lry-cleaning plants.

Sections of the circular are devoted to automobile and furniture polishes, metal polish, shoe polish, polishing clotlis, dust cloths, sweeping compounds, and wall-paper cleaner. A list of the Government specifications for the products covered, numerous references. and sugrested formulas for some items are included. Recommended specifications for two grades of laundry soap are given in the appendixes.

Copies of this circular (Burean of Standards C383) may be obtained from the Superintendent of Documents, Gorermment Printing Office, Washington, D). C. at 10 cents each.

\section{NEW DESIGN OF PRECISION RESISTANCE STANDARD}

Precision electrical resistance standards of the types now in general use slowly drift in resistance. For standards of good quality this change does not exceed a few parts in a million per year, but eren this is oljectionable in standinds nsed to maintain the mit of resistance.

A decided improvenent has been obtained at the National Burean of Standards by winding the resistance roils of bale wire on a mandrel and anuealing 
them at a red heat. The coils are removed and mounted on silk-covered brass tubes which form the inner walls of sealed containers of a new design. These containers are made of coaxial brass tubes closed at both ends with brass rings soldered to the tubes. The leads are introduced through small holes in the walls of the inner tubes; the holes being covered with plates of sheet copper and sealed with melted gum shellac. Presumably these containers will remain sealed indefinitely, while those which are closed with hard rubber caps are apt to leak after a few years. No oil or other cooling liquid is put into these new containers.

\section{TENTATIVE SPECIFICATION DEVELOPED FOR STAINLESS LUBRICANT}

Oil stains have for years been a source of considerable difficulty to hosiery and underwear manufacturers. The yarn comes in contact with certain movable parts of the knitting machines and it is not practicable to provide for satisfactory lubrication of the machine, and at the same time protect the fabric from occasional spots of oil. Because of the conditions of manufacture, the knitted fabric is stored, sometimes for months, before it is dyed and finished. During this time impurities in the oils oxidize and prodnce stains which are difficult, if not impossible, to remove in the subsequent processes.

The studies which were undertaken by the National Association of Hosiery and Underwear Manufacturers and the National Bureau of Standards, with the cooperation of a number of oil refiners, have resulted in a tentative specification for a stainless lubricant. Practical trials of oil complying with this specification have been in progress in three large hosier'y mills for a period of six months. Reports from the mills both as to the stainless character of this oil and as to its good lubricating qualities have been satisfactory. It is expected that this study will be completed during the coming winter.

\section{TO REDUCE WASTE IN DISTRIBUTION OF MERCHANDISE}

\section{Surveys Show Need of Applying Principles of Simplified Practice}

It has been reported that there are more than 6,000 department stores in the United States, exclusive of specialty stores, doing a total annual business of approximately $\$ 6,500,000,000$. Each year these stores buy wrapping and packing supplies valued at more than $\$ 25,000,000$ to which must be added the labor and other costs of distributing about $3,000,000,000$ packages.

There are two methods of improving this distribution function to give better service at less cost. First, to develop simplified practice in order to eliminate unnecessary sizes and varieties of packing supplies. Second, through a study of present practice, to develop recommendations describing efficient and economical methods of folding and preparing merchandise for delivery.

In the fall of 1929 the committee on simplification and standardization of the National Retail Dry Goods
Association requested the National Bureau of Standards, through its division of simplified practice, to collect data on the methods and materials used by department stores in the wrapping and packing of merchandise.

On September 17, 1930, the bureau furnished the committee with data collected during a four months: survey covering the actual current practice in 34 department stores. These stor'es, representing an aggregate sale volume of nearly $\$ 600,000,000$ a year, were selected to give a wide range of local conditions. In addition to specialty dry goods stores, large and small department stores, there was included one large organization doing an extensive mail-order business. The survey covered methods and supplies used for both ordinary and gift wrapping. These were further classified according to the type of transaction as follows :

Talies.-Merchandise taken by customer.

Sends.-Merchandise delivered to customer by wagon, truck, or other type of store delivery system.

Common carier.-Merchandise delivered to customer by parcel post, freight, or express.

The actual field work was conducted throughout the entire year, so that it was possible to observe the effect on packing practice caused by seasonal variation in merchandise. Geographical distribution was also a factor in so far as it disclosed buying habits and customer requirements.

The committee plans to use the material contained in the report $(a)$ to develop simplified practice recommendations covering sizes and varieties for packing supplies and (b) to develop recommendations to the department stores as to the most efficient and economical methods of folding and preparing merchandise for delivery. 'The committee expects to complete a large part of this work in time to present it to the annual meeting of the National Retail Dry Goods Association scheduled to be held in February, 1931.

The National Bureau of Standards will be glad to send a summary of its complete report to anyone requesting a copy.

\section{ARCHITECTS IN FINLAND STUDYING STAND- ARDIZATION OF PLYWOOD DOORS}

The board of directors of the Architects Association in Finland is now considering a plan for the standardization of smooth surface plywood doors, according to information received from C. Roderick Matheson, acting commercial attaché at Helsingfors, Finland. Under the plan proposed these doors would be standardized at widths of $500,600,700$, 800,900 , and 1,000 millimeters and at a height of either 2,050 or 2,100 millimeter's.

It is said that in addition to facilitating the work of local architects in Finland, the production costs at the plywood factories could be lowered to such an extent as to enable them to produce quantities at competitive prices for export.

\section{MANUFACTURE OF WALL PAPER 70 PER CENT ON STANDARD SPECIFICATION}

A survey among the manufacturers, recently completed to determine adherence, indicated that approxi- 
mately 70 per cent of the wall paper manufactured during the first six months of 1930 was made according to the commercial standard specifications.

The survey indicated that numerous concerns who previously made only very cheap ungrounded wall paper are now including in their line some papers that meet the standard of quality established in the commercial standard specifications.

An effective campaign on the part of the IVallpaper Association of the United States in promoting the use of these standards has been exceedingly successful and the general quality level of wall paper manufactured has thereby been increased.

The ability of manufacturers to guarantee the quality of their wall paper as conforming to the standard and, on the other hand, the ability of the householder to purchase wall paper of known quality as a result of the establishment of this standard has been of mutual benefit which should go a long way toward building good will for the industry.

The standard was reaffirmed by the standing committee in its present form for another year.

\section{PAMPHLET ON AMERICAN NATIONAL STAND- ARD SCREW THREADS AVAILABLE}

The pamphlet entitled "American National Standard Screw 'Threads, Commercial Standard CS24-30" has been released by the Government Printing Office, and was distributed to acceptors of record on October 13. This commercial standard makes available for convenient shop use the most important screw-thread dimensions and tolerances for classes $1,2,3$, and 4 fits as described in the American National Screw Thread Series and Fine-Screw Thread Series, as well as sizes and tolerances for tap drills for both of these series. The pamphlet includes a brief history of the project as developed by the National Screw Thread Commission, which is to serve as the standing committee. It also includes a list of acceptors of the standard.

\section{SUCCESS OF MIRROR STANDARD ASSURED}

On October 15 a circular letter was sent to the interested manufacturers, distributors, and consumers announcing the success of the project for the establishment of a commercial standard for plate-glass mirrors.

The success of this undertaking was made possible by the cooperation of over 215 acceptors, which includes approximately 80 per cent of the mirror manufacturing industry by production volume and many of the more important distributors, and consumer organizations.

The standard provides for five distinct grades of quality which follow closely after the existing grades of mirror plate. The defects allowable in the several grades are plainly indicated, and a common understanding of the several qualities will provide a more intelligent basis of comparison which should work to the mutual advantage of manufacturer, distributor, and purchaser. Various colored labels have been designated to represent each of the five grades and the use of these labels on the face side of the mirror was left optional with the manufacturer.

The standard will become effective for new production on December 15, 1930, and copies in mimeographed form are now available from the division of trade standards, National Bureau of Standards, Washington, D. C.

\section{STANDARDIZATION OF MOP STICKS}

The success of the project on the standardization of mop sticks was announced in a circular letter issued by the division of trade standards on September 15 .

This standard covers the size and quality of the various parts entering into the construction of mop sticks used in domestic and janitor service. Two types, which constitute by far the majority of mov sticks in general use, are covered in the commercial standard specifications. These types are known as the spring-lever type and the janitor screw type.

Those interested in the production, sale, or use of mop sticks may secure copies of the standard in mimeographed form from the division of trade standards, National Bureau of Standards, Washinoton, D. C.

\section{VITREOUS CHINA PLUMBING-FIXTURE STANDARD}

Industry to Distribute 40,000 Copies

The Manufacturers Advisory Committee on Vitreous China Plumbing Fixtures, at a recent meeting held at the National Bureau of Standards, decided to distribute 40,000 copies of the pamphlet entitled "Staple Vitreous China Plumbing Fixtures, Commercial Standard CS20-30" to all plumbers, plumbing jobbers, and architects in the United States. The committee has ordered the necessary copies from the Superintendent of Documents, and distribution will be made with the cooperation of the American Institute of Architects and the Plumbing and Heating Industries Bureatl.

\section{NEW AND REVISED PUBLICATIONS ISSUED BY THE BUREAU OF STANDARDS ${ }^{1}$}

Accelerated Tests of Asphalts. RP 19\%. Price, 10 cents.

American National Standard Screw Threads. (Coarse and fine threarl series.) CS24-30. Price, 10 cents.

American National Standald Screw Threads. CS25-30. Price, 15 cents.

Bearing Bronzes with Additions of Zinc, I'hosphorus Nickel, and Antimony. IRI' 205. Price, 15 cents.

Calorimetric Determination of Thermal Properties of Satu. rated Water and Steam from $0^{\circ}$ to $270^{\circ}$ C. RP 209 . Price, 20 cents.

Coeflicient of Iriction of Fabrics. RP 196 . l'rice, 5 cents. Color for School Furniture. R111-30. Price, 5 cents. Conductivity and Density of Chrouric Acid Solutions. RI' 198. I'rice, 5 cents.

${ }^{1}$ Send orders for these publications direct to the Superintendent of Documents, Govermment Frinting offce, Washington, $\mathrm{D}, \mathrm{C}$. 
Copper Electrotyping. C3s7. P'rice, 10 cents.

Cutting 'Tests with Cemented Tungsten Carbide Lathe Tools. IiP 206. Price, 10 cents.

Effects of Gases on Photo-Ionization of Caesium by line Absorption. RP 20s. Price. 5 cents.

Elastic Shoe Goring. IR112-29. Price, 5 cents.

Fire Clays; Some Fundamental Properties at Sereral Tenperatures. RP 194. Price, 10 cents.

Heat Transfer Through Metal-Inclosed Insulation. RP 207. Price, 5 cents.

Method of Measuring Frictional Coefficients of Walkway Materials. RP 204. Price 10 cents.

New Design of Precision Resistance Standard. RP 201. Price 5 cents.
Phase Equilibria in the System $\mathrm{Cr}^{\circ}, \mathrm{O}_{3}-\mathrm{SiO} . . \quad \mathrm{RP} 203$. Price, cents.

Precipitation and Ignition of Magnesium Ammonium Phosphate, RP 200. Price, 5 cents.

Precise and Rapid Method of Measuring Frequencies from 5 to 200 Cycles per Second. RP 195 . Price, 5 cents.

Preliminary Studies of the Effect of Dioxidation and Hold Conditions on the Tensile Properties of Carbon Steel Castings. RP 199. Price, 5 cents.

Simplification of Sizes and Terminology of High Volatile Bituminous Coal. II 113. Price, 5 cents.

Structure of the Spectra of Doubly and Trebly Ionized Zirconium. RP 202. Price, 10 cents.

Washing, Cleaning, and Polishing Materials. C 383. Price, 10 cents. 


\section{SCIENTIFIC, TECHNICAL, AND COMMERCIAL PERIODICAL PUBLICATIONS ISSUED BY THE NATIONAL BUREAU OF STANDARDS}

\section{BUREAU OF STANDARDS \\ JOURNAL OF RESEARCH}

The new Journal describes the bureau's research results in science and technology. The union of science and its applications in one journal shortens the lag between discovery and application.

All engaged in industry and commerce should have available for current use and permanent reference, the Bureau of Standards Journal of Research.

Early in its first year the Journal developed a list of paid subscribers double the anticipated maximum.

This Journal is full of interest to executives and technicians controlling industries and commercial enterprises. It enables them better to promote efficiency by determining the scientific measu red controls of process through experimental and theoretical research.

Issued monthly

Subscription price, $\$ 2.75$ per year

\section{COMMERCIAL STANDARDS MONTHLY}

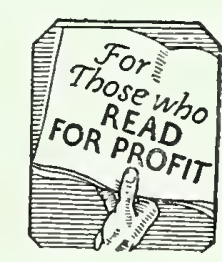

\section{TECHNICAL NEWS BULLETIN}

The Bureau of Standards periodical with a WAR RECORD! Started during the dark days of 1917 to keep the Army and Navy and other branches of the Government informed of progress in scientific war research at the bureau. Upon urgent request this publication was continued and expanded to serve the Government, science, and industry.

The TECHNICAL NEWS BULLETIN will keep you informed of current progress in the scientific and technical work of the bureau's laboratories, and gives each month a list of the publications of the bureau. A complete cross index is published with the December issue.

You can not afford to be without the TECHNICAL NEWS BULLETIN. Every article is short and to the point. The busiest executive can afford the time to read it.

Issued monthly

Subscription price, 25 cents per year

\section{STANDARDS YEARBOOK FOR 1930}

This new governmental periodical is a review of progress in commercial simplification and standardization. It is the oniy journal of its kind. It covers the national movement initiated by President Hoover for the reduction of needless sizes and varieties of products and the promotion of voluntary commercial standardization by industry.

The Secretary of Commerce in the first issue of this new journal said: "Certain standards, such as those used for weights and measures, * * * have been fixed by legislative enactment. Mandatory standards of this character, however, are few in number when compared with the large and steadily growing volume of standards developed by industry and commerce and voluntarily maintained. * * * The activities of the Commercial Standardization Group of the Bureau of Standards are concerned with standards adopted by voluntary agreement."

Subscription price, $\$ 1$ per year
The new Standards Yearbook for 1930 is the fourth annual issue of a publication devoted to the great and growing field of standardization in its broad aspects. It gives a summary of progress.

Standardization is a world-wide movement. It covers all industries. It is part of the application of scientific methods to industry. Its achievements are of interest and concern to business men and manufacturers as well as to engineers. To the technician it is full of example of methods and results of suggestive and stimulating value. To business men it discloses trends which deeply concern their interest.

\section{NOW READY Price, 75c. ORDER AT ONCE}

"Standardization is becoming an aspect of all wellordered activity rather than an incidental activity supplemental to others."

To obtain regularly the above-described monthly periodicals send your order, with remittance, addressed: Superintendent of Documents, Government Printing Office, Washington, D. C. Foreign prices (countries other than the United States and its possessions, Canada, Mexico, Newfoundland, Cuba, and Republic of Panama) are: Journal, \$3.75; Bulletin, $\$ 0.40$; Monthly, $\$ 1.25$; Yearbook, $\$ 0.90$ 
“*** this department $* * *$ is devoted solely to aiding and fostering the development of higher standards of living and comfort of our people $* * *$ its ideals are clear: That by cooperation and not by compulsion it should seek to assist in maintaining and giving the impulse of progress to commerce and industry in a nation whose successful economic life underlies advancement in every other field." - President Hoover, at the laying of the corner stone of the new building of the U. S. Department of Commerce, June 10, 1929.

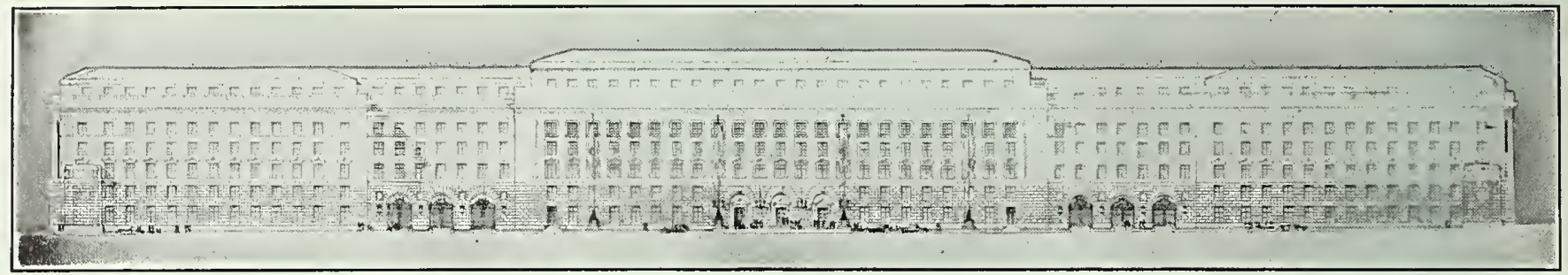

\section{THE UNITED STATES DEPARTMENT OF COMMERCE}

\section{R. P. LAMONT, Secretary of Commerce}

aEronautics BRanch, Charence M. Young, Assistant Secretary of Commerce for Aeronautics.

Establishment of civil airways and maintenance of aids to air navigation; inspection and registration of aircraft and licensing of pilots; enforcement of air trafic rules; investigation of accidents; encouragement of municipal air ports; fostering of air commerce; scientific research in aeronautics; and dissemination of information relating to commercial aeronautics. (Some of these functions are performed by special divisions of the Lighthouse Service, the Bureau of Standards, and the Coast and Geodetic Survey.)

BUREAU OF THE CENSUS, William M. Steuart, Director.

Taking censuses of population, mines and quarries, water transportation, and religious bodies every 10 years; censuses of agriculture and electrical public utilities every 5 years; and a census of manufactures every 2 years. Compilation of statistics of wealth, public debt and taxation, including financial statistics of local governments, every 10 years; annual compilation of financial statistics of State and municipal governments

Compilation of statistics of marriage, divorce, births, deaths, and penal and other institutions annually, and of death rates in cities and automobile accidents weekly.

Compilation quarterly or monthly of statistics on cotton, wool, leather, and other industries; annually of forest products; and publication monthly of Survey of Current Business.

\section{BUREAU OF FOREIGN AND DOMESTIC COMMERCE,} William L. Cooper, Director.

The collection of timely information concerning world market conditions and openings for American products in foreign countries, through commercial attachés, trade commissioners, and consular officers, and its distribution through weekly Commerce Reports, bulletins, confidential circulars, the news and trade press, and district and cooperative offices in 65 cities. The maintenance of commodity, technical, and regional divisions to afford special service to American exporters and manufacturers.

The compilation and distribution of lists of possible buyers and agents for American products in all parts of the world and publication of weekly lists of specific sales opportunities abroad.

The publicity of statistics on imports and exports.

The study of the processes of domestic trade and commerce. BUREAU OF STANDARDS, George K. Burgess, Director.

Custody, development, and construction of standards of measurement, quality, performance, or practice; comparison of standards used by scientific or other institutions; determination of physical constants and properties of materials; researches and tests on materials and processes; and publication of scientific and technical bulletins reporting results of researches and fundamental technical data.

Collection and dissemination of information concerning building codes and the planning and construction of holises.

Establishment of simplified commercial practices through cooperation with business organizations in order to reduce the wastes resulting from excessive variety in commodities.

BUREAU OF MINES, Scott Turner, Director.

Technical investigations in the mining, preparation, and utilization of minerals, including the study of mine hazards and safety methods and of improved methods in the production and use of minerals.

Testing of Government fuels and management of the Government Fuel Yard at Washington.

Research on helium and operation of plants producing it.

\section{BUREAU OF MINES-Continued.}

Studies in the economics and marketing of minerals and collection of statistics on mineral resources and mine accidents.

The dissemination of results of technical and economic researches in bulletins, technical papers, mineral resources series, miners' circulars, and miscellaneous publications.

BUREAU OF FISHERIES, Henry O'Malley, Commissioner.

The propagation and distribution of food fish and shellfish, in order to prevent the depletion of the fisheries; investigations to promote conservation of fishery resources; the development of commercial fisheries and agriculture; study of fishery methods, improvements in merchandising, and collection of fishery statistics; administration of Alaska fisheries and fur seals; and the protection of sponges off the coast of Florida.

bUReau of highthouses, George R. Putnam, Commissioner.

Maintenance of lighthouses and other aids to water navigation. Establishment and maintenance of aids to navigation along civil airways. Publication of Light Lists, Buoy Lists, and Notices to Mariners.

\section{COAST AND GEODETIC SURVEY, R. S. PATton, Director}

Survey of the coasts of the United States and publication of charts for the navigation of the adjacent waters, including Alaska, the Philippine Islands, Hawaii, Porto Rico, the Virgin Islands, and the Canal Zone; interior control surveys; magnetic surveys; tide and current observations; and seismological investigations. Publication of results through charts, coast pilots, tide tables, current tables, and special publications.

BUREAU OF NAVIGATION, Arthur J. Tyrer, Commissioner Superintendence of commercial marine and merchant seamen. Supervision of registering, enrolling, licensing, numbering, etc., of vessels under the United States flag, and the annual publication of a list of such vessels.

Enforcement of the navigation and steamboat inspection laws, including imposition of fees, fines, tonnage taxes, etc.

STEAMBOAT INSPECTION SERVICE, DICKERSON N. Hoover, Supervising Inspector General.

The inspection of merchant vessels, including boilers, hulls, and life-saving equipment, licensing of officers of vessels, certification of able seamen and lifeboat men, and the investigation of violations of steamboat inspection laws.

UNITED STATES PATENT OFFICE, Thomas E. Robertson Commissioner.

The granting of patents and the registration of trade-marks, prints, and labels after technical examination and judicial proceedings.

Maintenance of library with public search room, containing copies of foreign and United States patents and trade-marks. Recording bills of sale, assignments, etc., relating to patents and trade-marks. Furnishing copies of records pertaining to patents. Publication of the weekly Official Gazette, showing the patents and trade-marks issuer.

\section{RADIO Division, W. D. Terreli, Chief.}

Inspection of radio stations on ships; inspection of radio stations on shore, including broadcasting stations; licensing radio operators; assigning station call letters; enforcing the terms of the International Radiotelegraphic Convention; and examining and settling international radio accounts. 